\title{
Cacao-based Agroforestry in Conservation Forest Area: Farmer Participation, Main Commodities and Its Contribution to the Local Production and Economy
}

Murniati $^{1, *(D)}$, Sri Suharti ${ }^{1}$, Irma Yeny ${ }^{1}$, and Minarningsih ${ }^{1}$

\begin{abstract}
Cacao-based agroforestry systems have been developed in the conservation forest area of Wan Abdul Rachman Grand Forest Park (WAR GFP). Previously, the forest areas were occupied by surrounding needy communities, causing land-use conflict and forest degradation. To resolve these problems, the conservation forest manager developed a conservation partnership program, giving farmers legal access to establish cacao agroforestry systems while improving forest conditions. This research aimed to study the farmers' participation, main commodities of the cacao-based agroforestry system, and its contribution to the local production and economy. This research was conducted in 2018 and 2019. The field survey was used to characterize the agroforestry system practiced and a series of interviews with two respondent groups, stakeholders concerned with WAR GFP management (nine key informants), and cacao-based agroforestry farmers ( 61 respondents). The agroforestry systems were dominated by cacao trees mixed with other tree crops and forest trees with an average density of $1,169.3 \pm 668.3$ trees/ha. Community involvement in the agroforestry development has only reached "Placation" or level 5 of Arnstein's participation ranking, implying they are granted limited opportunities to participate in the agroforestry development. Cacao production was influenced by the cacao tree and the associated tree density. Optimal cacao production as much as $367.4 \pm 357.9 \mathrm{~kg} / \mathrm{ha}$ was achieved at 1,253 trees/ha of total tree density. Besides cocoa, there were 13 primary commodities, where some have contributed more than $40 \%$ to district production. Income gained from the agroforestry systems contributes significantly $(75.63 \%)$ to total farmers' income. It can fulfill households' basic needs and has exceeded the poverty line at the national level. The cacao-based agroforestry development has become an alternative to resolve land use conflict in conservation forest areas characterized by land scarcity with a dense population.
\end{abstract}

\section{KEYWORDS}

Community participation; Farmer income; Income contribution; Local economy; Main commodities; Tree crop yield.

\section{INTRODUCTION}

Conservation forest areas in Indonesia face significant and complex pressures, which in many cases, cause habitat degradation. Most of Indonesia's population still depends on forest resources. Of the 74,954 villages in Indonesia, more than 25,800 villages (34\%) are located in or at the forest boundaries. Of all the villages, 6,381 are inside or at the fringes of the nearly 22 million hectares of Conservation Forest and strongly depend on the forest for their livelihoods (Ministry of Environment and Forestry, 2020). This confirms previous research suggesting that forest-dense areas are often associated with high poverty levels due to the remote location with limited access to markets, information, services, and minimum infrastructure facilities (Chomitz, 2007). 
Currently, in many countries, agricultural development no longer focuses only on boosting production. In addition to food diversification, economic added value, competitiveness and improvement of farmers' wealth, and self-sufficiency, sustainable agriculture has become the main agendas. Programs to increase income and management capacity for farming and agribusiness towards Good Agricultural Practices and Good Farming Practices application of science and technology, and concern for the conservation of physical, genetic, and environmental resources have become top priorities now. Wan Abdul Rahman (WAR), one of Grand Forest Parks (GFP) located in Lampung Province, Sumatera Island is surrounded by villages with forest dependent communities to fulfill their basic necessities. Agricultural land scarcity and economic pressure have caused forest land encroachment to occur extensively on this forest park for decades (Wulandari et al., 2018; Minarningsih \& Murniati, 2020).

To prevent from further land and forest degradation, efforts have been made by accommodating farmers' interest to get involved in conservation forest management while improving forest condition through "conservation partnership program". The program launched by the Indonesian Government in 2018 allows the communities to manage and take benefits from the conservation forest areas, but with several restrictions. A restriction determined by the forest park management authority induced the farmers to cultivate in the conservation forest land by applying agroforestry systems (Wulandari et al., 2014; Handoko \& Darmawan, 2015). Agroforestry, a land management system that combines forest trees with agricultural tree crops is a more efficient land use and production input strategy to optimize production and income per unit area, which refers to the principle of sustainable, multipurpose, and optimal production, with management techniques suited to local culture. Agroforestry is also an alternative solution to the problem of agricultural economic development, which faces scarcity and a decrease in the quality of agricultural land resources (Jumiyati et al., 2018).

Although providing management access to surrounding forest communities poses the risk of declining forest function due to reduced forest cover and vegetation stratification, entrusting forest sustainability to the community to maintain existing forest trees while increasing forest diversity with various plant species, such as multipurpose tree species (MPTS), has been proved to increase forest land cover significantly. This indicates that the community plays a vital role in the sustainable management of the forest surrounded by densely populated villages. Previous research shows that the involvement of surrounding communities in forest park management through agroforestry development has changed the structure and composition of the forest into a complex agroforestry system dominated by food-producing plants. The most dominant species that grow well in the area is cacao (Theobroma cacao L.) (Minarningsih \& Murniati, 2020). Braga et al. (2018) stated that agroforestry systems are important agricultural land use that synergizes with socio-environmental aspects, especially with cacao crop, a commodity mainly produced by smallholders in the humid tropics.

In humid tropical areas, most cacao cultivation is developed in agroforestry systems and grown in association with forest trees or MPTS with high environmental, social, and economic value that is planted and maintained after partial forest clearing (Notaro, 2020; Essouma et al., 2020; Jagoret et al., 2014; Berlan \& Berges, 2013).

Niehaus (2011), in his study, found that cocoa production cultivated by surrounding forest communities mostly comes from forests with high biodiversity. 
Organic, shade-grown cacao has been described as one of the best examples of permanent agriculture that in some ways preserves a forest environment (Ruf \& Schroth, 2004) and supports higher biodiversity levels than most other tropical crops (Rice \& Greenberg, 2000). Although cacao-based agroforestry is generally less diverse and less dense than the reserved natural forest, it is enriched with exotic and indigenous fruit tree species and other Agroforestry Tree Products (AFTPs) to meet household needs (Oke \& Odebiyi, 2007). This system has increasingly received attention for sustainable agricultural land use that meets biological, ecological, and economic objectives. It also provides important crops to improve the livelihoods of local communities (Duguma et al., 2001; Parrish et al., 1998; Rice \& Greenberg, 2000; Schroth et al., 2004).

Therefore, cacao-based agroforestry is a promising alternative to solve land use conflicts in areas characterized by land scarcity with dense population. It can also become a model for resolving the decrease in the quality of agricultural land resources in many tropical countries. However, studies related to the development of cacao-based agroforestry in a conservation forest area are still rare. This research aimed to study farmers' participation, main commodities of the cacao-based agroforestry system developed in Wan Abdul Rachman Grand Forest Park (WAR GFP), and its contribution to the local production and economy.

\section{THE RESEARCH METHOD}

\subsection{Theoretical Framework}

The top-down approach of forest governance is nowadays not an appropriate approach to forest management, especially where the dependency of local communities on forest resources is high. To a greater extent, this kind of forest management has failed to achieve the desired goals of forest conservation and revenue generation. The failure of state-governed forest management and the subsequent misery of forest-dependent poor people have encouraged the governments and development agencies to involve local people in forest governance.

In the last three to four decades, this type of forest governance has undergone several changes, and community-based forest management (CBFM) has been established as a means of sustainable forest management, particularly in developing countries. The CBFM programs, popularly known as community forestry, social forestry, participatory forestry, and joint forest management, have been promoted in many countries as an innovative and potential approach to improved forest management and conservation strategies with a comprehensive blend of ecological and socio-economic objectives (Bowler et al., 2012; Moorman et al., 2013; Kalonga et al., 2015; Nath et al., 2016). In its implementation, CBFM is mostly done by applying agroforestry techniques as a form of sustainable intensification of agroecosystems. Sustainable intensification is defined as a process or system where production is increased without adverse environmental impact and the cultivation of more land (Pretty et al., 2011; Pretty \& Bharucha, 2014). Arnold (1987) mentioned that in many cases, many agroforestry practices are characteristic of simple resource-poor situations that are not easily adapted to more intensive agricultural practices with intensive use of capital, inputs, and equipment.

Meanwhile, forest village communities are generally characterized by narrow and even landless land ownership (Yeny et al., 2017; Murniati et al., 2019). Hence, agroforestry activities are critical in enabling farmers to optimize land use with limited resources (land, capital, access). In addition, the competition between trees and annual 
crops and people's priorities for fulfilling basic needs have limited options for agricultural activities, especially those developed in conservation forest areas with several restrictions. This situation commonly occurs in Indonesia, where villages with forest dependent communities surround most state forests, including conservation forest areas, like WAR GFP.

The community's entry into conservation forest areas is an undeniable fact, and the assumption that forest surrounding communities are often considered forest squatters has caused tenure conflict. However, since the community has existed for a long time, repressive actions cannot be taken severely, and therefore, a special approach is needed. To balance between the interests of conservation and the economic needs of the communities, the Government of Indonesia, in this case, the Ministry of Environment and Forestry, issued Regulation of the Director General of Natural Resources and Ecosystems Conservation No. P.6/KSDAE/SET/Kum.1/6/2018 concerning Conservation Partnerships in Nature Reserves and Nature Conservation Areas.

Provision of access allows the community to get benefits legally from the forest while being involved in forest management. Uphoff (1992) and Ostrom (1990) stated that efforts to involve communities to take responsibility in natural resource management would be more accessible if they could receive benefits immediately, locally, and in real time. Conversely, in a situation where the benefits from certain activities to be received are out of reach (remote), long, and challenging to identify, efforts to sustainable resource management will be complicated. To evaluate how far the community has been involved in developing cacao-based agroforestry through a conservation partnership scheme in the WAR GFP area, we use Arnstein's concept of participation which classifies the level of participation into 8 levels.

\subsection{The Research Site and Time}

This study focuses on cacao-based agroforestry system developed in conservation forest of WAR GFP which is managed by the forest surrounding community. The survey was conducted in two villages, namely Bogorejo (which belongs to Gedong Tataan SubDistrict) and Cilimus (Teluk Pandan Sub-District), Pesawaran Regency, Lampung Province, Indonesia (Figure 1). Pesawaran Regency is located between $05.12^{\circ}-05.84^{\circ} \mathrm{S}$ and $104.92^{\circ}-105.34^{\circ}$ E (BPS-Statistics of Pesawaran Regency, 2020). Meanwhile, WAR GFP lays between $05^{\circ} 23^{\prime} 47^{\prime \prime}$ to $05^{\circ} 30^{\prime} 35^{\prime \prime} S$ and $105^{\circ} 02^{\prime} 42^{\prime \prime}$ to $105^{\circ} 13^{\prime} 42^{\prime \prime} E$ with an area cover of 22,245.50 ha (UPTD Tahura WAR, 2017). The research was conducted from 2018 to 2019.

The cacao agroforestry area is located in traditional block of WAR GFP. The traditional block covers $13,799.37$ ha or about $62.03 \%$ of WAR GFP total area. There are 7,230 agroforestry farmers who occupied about 8,880 ha of forest land in the conservation forest. The farmers were incorporated into 35 farmer group alliances (UPTD Tahura WAR, 2017).

\subsection{Research Method and Data Collection}

Two methods were employed in this research, namely field observation, and interview. Field observation was done on several cacao-based agroforestry plots to characterize the practiced farming system, including planting pattern, dominant plant species, the harvesting, main products, and post-harvest product processing such as stripping and drying. A Series of interviews was carried out with two respondents, i.e., stakeholders concerned with the forest park management (nine key informants) and 
farmers of cacao-based agroforestry (61 respondents). Those key informants were selected purposively, including head of the forest park, head of forest resort, forest extensions, forest police, villages heads, and leaders of forest farmer group alliances to evaluate how far the community has been involved in WAR GFP management. It includes the process of the cacao agroforestry system development, community participation, farmer group empowerment, and conflict resolution.
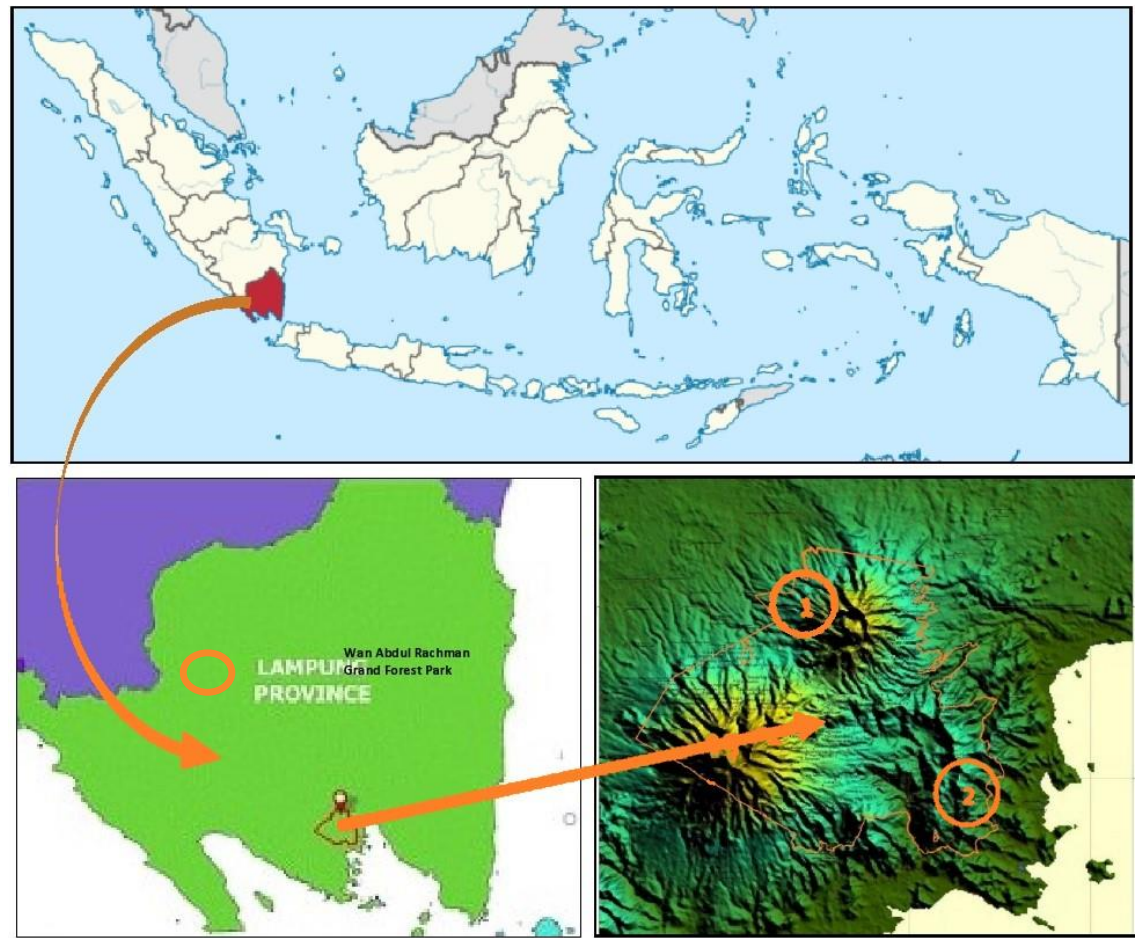

Figure 1. The research site in Wan Abdul Rachman Grand Forest Park area, Lampung Province, Indonesia (Orepresent research villages, 1. Bogorejo, 2. Cilimus)

Many studies related to farmer participation from the perspective of farmers in forest management have been carried out, including in WAR GFP (Wulandari et al., 2014; Mshale et al., 2017; Alfandi et al., 2019; Mak et al., 2017; He et al., 2020; Astuti \& Simarmata, 2020). This study looks at farmer participation from the perspective of relevant stakeholders and evaluates the level of participation using Arnstein's theory (1969). Meanwhile, 61 farmer respondents were selected purposively based on certain criteria. The participants practiced the agroforestry system at WAR GFP, settled in the two research villages, and became a member of the forest farmer groups. They were involved in obtaining information on cacao-based agroforestry system covering characteristics of the agroforestry system, cultivation methods, species and number of cultivated and natural growing plants (productive and unproductive), plants' production, farmer income from the cacao agroforestry system in WAR GFP, from farming on their own land and from off-farm activities. 


\subsection{Data Analysis}

Data analysis was carried out descriptively applying several analysis tools. The analysis uses a system approach, consist of analyzing the existing components in the agroforestry system and analyzing the linkages between the participation components, types and species of tree crops cultivated, production and income, and whether they are mutually supporting or opposing. The data analysis stages are as follows:

1) Identifying characteristics of cacao-based agroforestry pattern including farmer characteristics, plant types and species, plant condition (productive and unproductive).

2) Identifying plant density. The calculation of plant number per hectare of certain species (plant density) and density of each plant classification is as follows (eq. 1):

$$
\text { Plant density of species } i=\frac{\text { Number of plant of species } i}{\text { Total agroforestry area }}
$$

Plant classification density $x=$ Total density of plant of some species belonging to plant classification $x$

3) Analyzing farmers' participation in cacao-based agroforestry development after getting access right for land use in WAR GFP. The analysis focuses on the form/type and participation level according to Arnstein (1969). Measurement of participation level used Likert scale based on the degree of respondents' interaction in agroforestry activities. We formulated 12 questions related to participation level. The questions were answered at two levels, namely: yes/doing (scale value 2) and no/not doing (scale value 1).

To measure the score of an activity, the following formula was used (eq. 2):

$$
\text { Score }=\text { Scale value } x \text { number of respondents } x \text { number of questions }
$$

The results of the scores of all these variables were used to measure the degree of involvement in various cacao-based agroforestry farming activities. The minimum and maximum scores were obtained by the following formula (eq. $3 \&$ 4):

Minimum score $=$ number of questions $x$ number of respondents $x$ lowest score (3)

Maximum score $=$ number of questions $x$ number of respondents $x$ highest value (4) The interval between each participation level was calculated by subtracting the maximum with the minimum score divided by 8 participation levels.

4) Analyzing the production of cacao-based agroforestry including cocoa and other main products.

5) Analyzing the contribution of main cacao-based agroforestry products to local and regional production.

6) Analyzing farmers' income and contribution to the local economy

\section{RESULTS AND DISCUSSIONS}

\subsection{Development of Cacao-based Agroforestry Systems}

Most of the communities around Wan Abdul Rachman Grand Forest Park (WAR GFP) have cultivated the forest land for more than 20 years since most of them only own a tiny land. The average respondents' land ownership was only 0.16 ha, where most of them $(71 \%)$ have land $\leq 0.1 \mathrm{ha}$, and two respondents were landless. With relatively small land ownership, the farmers were hardly able to meet their daily needs, and then 
this condition induced them to encroach the forest area in WAR GFP since 1965 for agricultural crop cultivation. This has continued for decades, and the situation was worsened by increasing population and thus increasing pressure on the forest. In 1999 after the issuance of the Minister of Forestry No. 677/Kpts-II/1998 concerning Community Forestry Decrees, the community was granted a temporary community forestry permit ( 5 years period), and forest farmer groups were allowed to manage a forest area of 492.75 ha (Nurlia et al., 2015). Unfortunately, in 2004, the Government has canceled the policy on Community Forestry, and the community can no longer have legal access to participate in WAR GFP management resulting in the repetition of land encroachment. In 2012, through Provincial Regulation No. 3, a Collaborative Management scheme aiming to accommodate community needs and prevent future damage was developed within WAR GFP. Collaborative management allowed the community to cultivate the land inside WAR GFP with several restrictions. With this strategy, the land cover in WAR GFP has increased significantly. The change in forest cover in WAR GFP from 1994 to 2014 is presented in Figure 2 (Handoko \& Darmawan, 2015).

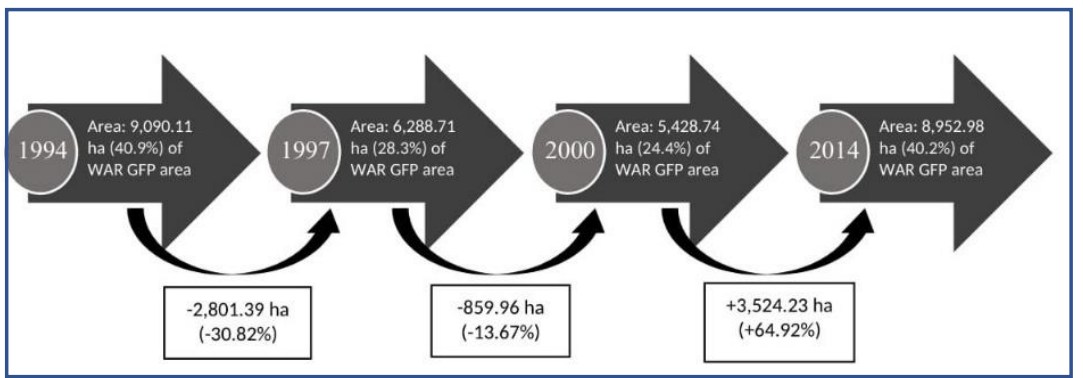

Figure 2. Change in forest cover in WAR GFP during the period of $1994-2014$

Landsat satellite imagery classification 1994 indicated that the forest cover was only 9,090.11 ha (40.9\%) of the total WAR GFP area. In 1997 and 2000, the forest cover declined to $28.3 \%$ and $24.2 \%$, respectively. In 2014, with the development of collaborative management that provided access to communities to utilize forest land with agroforestry techniques, forest cover increased significantly to $40.2 \%$. The cropping pattern developed in the collaborative management is agroforestry with a combination of rubber, cacao, MPTS, and forest trees. Communities can take advantage of Non-Timber Forest Products (NTFPs) to ensure their welfare and grow woody plants to preserve the forest (Nurlia et al., 2015). The success of collaborative management developed in WAR GFP proved that community participation was the key to the successful implementation of agroforestry (Handoko \& Darmawan, 2015).

In 2016, the Indonesian government launched the Minister of Environment and Forestry Decree No. 83 concerning Social Forestry, which momentum access rights allocation in forest management for surrounding forest communities. Through this policy, people who previously worked on forest land illegally were inventoried to become members of the Forestry Partnership, one of the Social Forestry Program schemes. Through this scheme, the community has access to get involved in the management of WAR GFP. Currently, the community developed a cacao-based agroforestry system in the forest land with an average area of $1.5 \mathrm{ha} / \mathrm{family}$, and the 
respondents' dominant farm size ranged from $>1.0$ to 2.0 ha (48\%) (Figure 3). The certainty of access rights in land management within the WAR GFP area eliminated tenure conflicts among farmers and between WAR GFP managers. This confirmed He et al. (2020), who argued that stable and flexible land tenure should be ensured so that the right to benefit can be guaranteed and become the critical success for community participation and collective action in sustainable resource management.

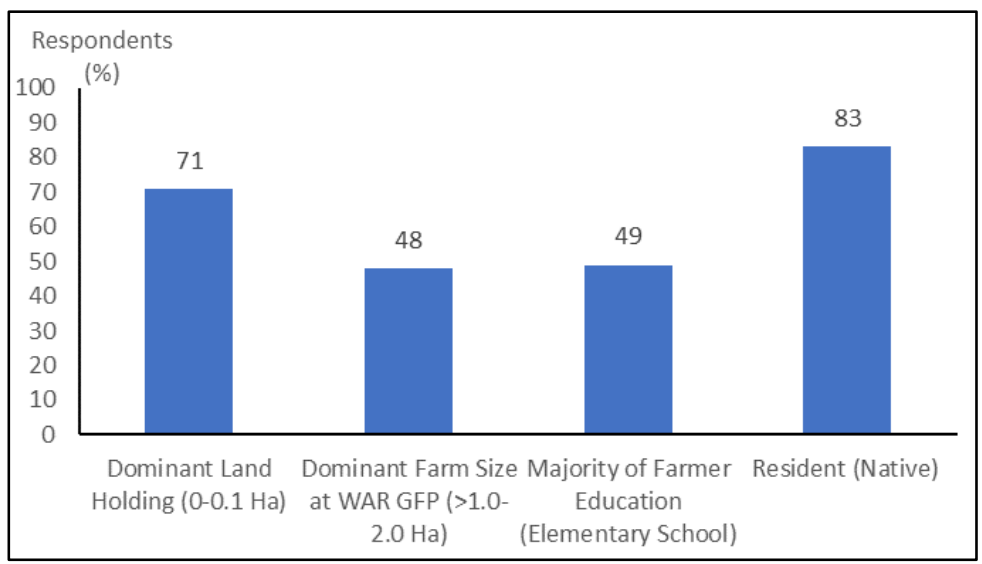

Figure 3. Characteristics of respondents of cacao-based agroforestry at WAR GFP, Lampung Province, Indonesia.

The cacao agroforestry farmers owned low formal education; nearly half of the respondents (49\%) graduated from elementary school, even some $(10 \%)$ never went to school at all. However, this farmers' education level is slightly better than that of cocoa agroforestry farmers in the Dominican Republic, where $74 \%$ of respondent farmers only graduated from elementary school, and even $14 \%$ of them had no formal education (Berlan \& Berges, 2013). Regarding the farmers' origin, the majority (83\%) were native, and only a few came from outside the region, such as from Java.

Most of the cacao agroforestry farmers cultivated their farms based on inherited knowledge. Only a few of them received training in cacao cultivation, such as nursery, plant maintenance, and post-harvest processing. Most of them managed their farm without sufficient capital; they only had family labor to cultivate the land. Based on those characteristics, we argue that the cacao-based agroforestry system at WAR GFP is vulnerable to smallholder farms. The farmers do not have enough capital or technical competence to intensify their farms. This is in line with the cacao agroforestry system developed in the Dominican Republic (Berlan \& Berges, 2013). The results of this study strengthen Arnold's theory which states that many agroforestry practices are characteristic of simple resource-poor situations and are not easily adapted to more intensive agricultural practices.

Cacao-based agroforestry systems were dominated by cacao trees (T. cacao) and associated with several plant types, such as food tree crops, cash tree crops, forest trees, and understorey species. Plant species classified as food tree crops included candlenut (Aleurites moluccana), “durian” (Durio zibethinus), "petai” (Parkia speciosa), "jengkol” (Archidendron pauciflorum), and clove (Syzygium aromaticum). Cash tree crops consisted of rubber (Hevea brasiliensis), kapok tree (Ceiba pentandra) and areca nut (Areca catechu). Meanwhile, forest tree species comprised mahogany (Swietenia 
macrophylla), "medang" (Litsea spp.) and "sonokeling" (Dalbergia latifolia). The understorey species included chili (Capsicum annuum), vanilla (Vanilla planifolia) and taro (Colocasia esculenta) (Table 1 and Table A1). Cacao-based agroforestry system practiced in the research site is in line with Deheuvels et al. (2014), Vebrova et al. (2013) and Cerda et al. (2014), who found that associated trees in cacao-based agroforestry support high species richness and diversity, and provide diverse products.

Most plants were planted without regular spacing except for cacao, coffee, and rubber. In general, associated trees were planted or grown scattered, while understorey species grew on the side-lines of the trees. Tree crop composition and structure of the cacao-based agroforestry systems were influenced by farmers' preferences for mixed plant species. Most farmers choose durian and candlenut as mixed tree crops since those plants have a high economic value with a canopy much higher than cacao. Therefore, cacao plants still get enough light intensity for optimal growth and yield. Shaded tree crops, such as cacao, provide habitats for numerous forest-dependent species of high conservation value and play a largely undocumented role in providing other ecological services (Deheuvels et al., 2014). Braga et al. (2018) found that there was a transition in the floristic composition associated with cacao agroforestry in Southern Para, Brazilian Amazon from Initial Shade (IS) to Secondary Shade (SS), wherein SS the species richness and diversity were greater than IS.

We found 56 plant species planted and/or naturally grown at the cacao-based agroforestry system, with the total area surveyed was 91.43 ha, managed by 61 farmers. Each farmer has 1,603 plants on average, with a total population (excluding understorey species) of 97,772 (Table 1 ). The high number of associated tree species in each farmer plot, i.e., $10.0 \pm 4.1$ (Table 4), has made cacao-based agroforestry become complex agroforestry systems. The dominant plant type was food tree crops, followed by cash crops, and forest tree species were at the lowest rank. Deheuvels et al. (2014) stated that complex agroforestry systems with high structural and functional plant diversity provided essential resources for biodiversity conservation, such as food and habitat.

According to the plant production function, they are differentiated into two categories: productive and unproductive plants. A plant is categorized as productive if it produces tangible products, like fruit, latex and other products that can be consumed and/or sold. An unproductive plant means that the plant has reached a mature stage but does not produce yield/fruit, produces decayed yield, or is just enough for household consumption. Immature plants are also categorized as unproductive plants. In this case, all forest trees are categorized as unproductive plants because they cannot be logged, used, and sold as the area is a conservation forest, where only non-timber forest products can be harvested. The forest trees produce intangible products, such as environmental services, but we only calculated tangible products in this context.

The number of unproductive plants was relatively high, which is $21.1 \%$. This may be caused by several factors. Some plants could not produce yield since they could not capture sufficient sunlight intensity as they grow under very high shade from the canopy of other trees. Some plants were attacked by pests and disease, causing crops to rot; the other cause was a small yield, just enough for own consumption. A detailed description of plant characteristics of cocoa-based agroforestry systems at WAR GFP is presented in Table A1. 
Table 1. Plants characteristics of cacao-based agroforestry systems at WAR GFP, Lampung Province, Indonesia

\begin{tabular}{cccccc}
\hline \multirow{2}{*}{ No. } & \multicolumn{1}{c}{ Type of plant } & Number of & \multicolumn{3}{c}{ Number of plants } \\
\cline { 3 - 6 } & & species & Productive & Un-productive & Total \\
\hline 1 & Food tree crop species & 24 & 65,185 & 11,668 & 76,853 \\
2 & Cash tree crop species & 3 & 11,999 & 8,490 & 20,489 \\
3 & Forest tree species & 19 & 0 & 430 & 430 \\
4 & Understorey species & 10 & - & - & - \\
& (food and spices crop) & & & & $\mathbf{9 7 , 7 7 2}$ \\
\hline
\end{tabular}

Remarks: Total respondents: 61 ; Total coverage areas: 91.43 ha

\subsection{Farmer Participation in Managing of Cacao-based Agroforestry}

\subsubsection{Forms of community participation in cacao-based agroforestry development}

Participation is a process to generate a feeling of being included or involved in a program activity (Suharti, 2001), although not all community involvement automatically encourages thorough community participation in program development. Community participation in cacao-based agroforestry management was carried out through various programs offered by the forest park management. Participation is especially expected in the utilization of the forest parkland through planting activities with different kinds of fruit and tree crops while adhering to the rules stipulated in the forest park and taking into account the area's sustainability. Farmers' positive understanding of their need to adopt agroforestry and the risks associated with the adoption are significant factors in tree planting decisions. Irshad et al. (2011) found that in Swat district, Pakistan, positive factors affecting tree planting emerged from farmers' understanding of agroforestry as a source of income and farmers' specific socio-economic characteristics, including age, education, size of land ownership, and several family members. This also occurred in the development of community-based forest management in West Java, where people's willingness to get involved in the intercropping program was influenced by benefits offered with an expectation of additional income (Parhusip et al., 2019).

Similar findings on factors that determine tree planting decisions were also found by Ndayambaje et al. (2012). Subsequently, Mahmood \& Zubair (2020) found that agroforestry was more likely to be adopted not only by farmers who understood the multipurpose benefits of agroforestry and had more experience in tree planting but also by those who are willing to invest in the long term ( $>5$ years) for bigger profit margin. Thus, farmers whose source of income only depends on agricultural crops will be less likely to adopt agroforestry practices. He et al. (2020) argued that the right to benefit from the forest and have access to utilize the forest with stable and flexible land tenure had been the leverage factor for community participation and collective action in sustainable resource management.

Yeny et al. (2020) classify participation into 5 forms, namely: 1 . Thought by conveying ideas/suggestions in meetings/discussions; 2. Labor assistances for physical development program and assistance to others; 3 . Material/property donations include money, food, and work equipment.; 4. Skill inputs to encourage various forms of business and industry; 5 . Social support as a sign of kinship/friendship. In cacao-based agroforestry development in WAR GFP, there are three forms of participation contributed by the community i.e., opinions, labor, and material inputs. The input of 
ideas was given during planning and preparation of technical plans, in this case, during the negotiation on zonation determination of WAR GFP. Some of the agreements reached, among others, were to define which areas are allowed and prohibited for community activities; arrangements related to planting permits and construction of water reservoirs; and community-leaders involvement in decision making. Contribution of labor and material was given by preparing seedlings and planting fruit trees independently as well as involvement in patrol and area protection activities.

Meanwhile, based on steps of participation, Uphoff (1985) divided it into four, which are (1) Participation in implementation, where the community is actively mobilized to take part in the implementation of the program and they are given responsibility for tasks; (2) Participation in evaluation, where after the achievement of the program, the community is invited to learn from the success or failure of its implementation; (3) Participation in benefits, where the community can enjoy the results of the program that has been implemented; and (4) Participation in decision making, where the community is invited to start preparing the concept of the program to be implemented. In this study, based on the research findings, we categorize community participation in cacao-based agroforestry development into three stages, which are planning, implementing, and monitoring (Table 2).

In the planning process, the community was involved in planning and preparation of technical plans, such as in the negotiation on zonation determination of WAR GFP. In the implementation process, the respondents stated that they had been involved in formulating roles and responsibilities related to developing cacao-based agroforestry in WAR GFP. They are not only an object of cooperation, but they have an active role in maintaining the sustainability of the land. The community's willingness to participate in the sustainable management of cacao-based agroforestry in WAR GFP cannot be separated from many benefits gained by getting legal access to cultivate and manage the land. In terms of management, various facilitations provided by WAR GFP management have significantly increased the community's commitment to engage actively in conserving the area.

Furthermore, it was found that respondents had taken the initiative to prepare seedlings both collecting from the forest and/or growing from sown seeds (22.22\%). There are $77.78 \%$ of respondents who planted empty areas with fruit tree species to improve the ecological condition of WAR GFP. The motivation to prepare seedlings and plant empty areas independently, according to Yeny et al. (2020), was contribution in the form of labor and cash donation. In the monitoring phase, all respondents (100\%) confirmed their willingness to get involved in several activities related to patrol and forest protection efforts (Table 2).

Table 2. Form and score of community's involvement in the management of cacaobased agroforestry in WAR GFP

\begin{tabular}{|c|c|c|c|c|}
\hline \multirow[t]{2}{*}{ No. } & \multirow[t]{2}{*}{ Description of Activities } & \multicolumn{2}{|c|}{$\begin{array}{c}\text { Community's } \\
\text { Involvement (\%) }\end{array}$} & \multirow{2}{*}{$\begin{array}{c}\text { Score of } \\
\text { Participation }\end{array}$} \\
\hline & & Yes & No & \\
\hline \multirow[t]{4}{*}{1} & Planning & & & \\
\hline & Negotiation in WAR GFP zoning & 100 & 0 & 18 \\
\hline & $\begin{array}{l}\text { Negotiation in planting and constructing } \\
\text { water reservoir }\end{array}$ & 100 & 0 & 18 \\
\hline & $\begin{array}{l}\text { Involvement of community leaders in the } \\
\text { agreeing of activities }\end{array}$ & 100 & 0 & 18 \\
\hline
\end{tabular}




\begin{tabular}{|c|c|c|c|c|}
\hline \multirow[t]{2}{*}{ No. } & \multirow[t]{2}{*}{ Description of Activities } & \multicolumn{2}{|c|}{$\begin{array}{c}\text { Community's } \\
\text { Involvement (\%) }\end{array}$} & \multirow{2}{*}{$\begin{array}{c}\text { Score of } \\
\text { Participation }\end{array}$} \\
\hline & & Yes & No & \\
\hline & $\begin{array}{l}\text { Defining sharing roles and } \\
\text { responsibilities }\end{array}$ & 100 & 0 & 18 \\
\hline & $\begin{array}{l}\text { Preparing seedling and developing } \\
\text { tourism }\end{array}$ & 22.22 & 77.78 & 4 \\
\hline & $\begin{array}{l}\text { Planting fruit trees (durian, petai, etc.) } \\
\text { independently }\end{array}$ & 77.78 & 22.22 & 14 \\
\hline & $\begin{array}{l}\text { Involvement in post-harvest processing } \\
\text { training (melinjo, banana), mushroom } \\
\text { and catfish cultivation, and product } \\
\text { marketing }\end{array}$ & 55.56 & 44.44 & 10 \\
\hline & $\begin{array}{l}\text { Involvement in land rehabilitation efforts } \\
\text { to increase forest cover }\end{array}$ & 55.56 & 44.44 & 10 \\
\hline \multirow[t]{6}{*}{3} & Monitoring of the program implementation & & & \\
\hline & $\begin{array}{l}\text { Involvement in patrol and forest } \\
\text { protection efforts }\end{array}$ & 100 & 0 & 18 \\
\hline & $\begin{array}{l}\text { Involvement in various efforts to resolve } \\
\text { land conflicts }\end{array}$ & 100 & 0 & 18 \\
\hline & $\begin{array}{l}\text { Involvement in various discussions } \\
\text { related to future policy and development } \\
\text { of WAR GFP }\end{array}$ & 77.78 & 22.22 & 14 \\
\hline & $\begin{array}{l}\text { Involvement in preparing conservation } \\
\text { cadres at the farmer level effort }\end{array}$ & 55.56 & 44.44 & 10 \\
\hline & $\begin{array}{l}\text { Average of Communities' Involvement } \\
\text { Total Score of Communities' Participation }\end{array}$ & 78.70 & 21.30 & 170 \\
\hline
\end{tabular}

Active participation of the communities in several forest protection efforts in WAR GFP had reduced the occurrence of illegal logging and tenure conflict, hence preventing forest degradation in the area. Furthermore, the active involvement of the community is also shown by the motivation to attend several discussions related to the future policy and development of cacao-based agroforestry. Their active involvement in several discussions with WAR GFP management increased their awareness about the significance of forest conservation for the continuation and the success of their cacaobased agroforestry. This is in line with Sikerbol (2016) study, which found that involving affected community in program development will minimize resistance to change initiatives and provide a perception of a greater sense of control during the change process. Control is an important factor in helping to cope with feelings of vulnerability and other emotional reactions that may be experienced during program development (Lewis \& Russ, 2012).

\subsubsection{Level of community participation}

The level of community participation indicates whether or not communities are willing to achieve cooperation goals independently (Winata \& Yuliana, 2012). According to Arnstein (1969), community participation is based on their ability to determine plans/programs. In general, there are eight steps of participation and three degree sets of participation. Level 1-2 in fact do not reflect participation. These two lowest levels merely aim to prevent community's dislike and they are implemented as if they were going to be involved in an activity. Levels 3-5 are at the power sharing level, where participation occurs only for formality. Meanwhile, level 6-8 is the level where there is 
power distribution and the community has the real right and power over a project/program activity. In this highest three level of participation, the community is given full authority to control and run a project/program development.

From the data analysis, we found that the interval score of eight participation ladders in cacao-based agroforestry development in WAR GFP is 15.4 and the community participation was at the 5th level of Arnstein's Ladder, that is "Placation" (Table 3). Placation implies that communities are solely granted limited opportunities to participate or influence a process, and their participation is simply tokenistic.

Placation does not give the community access to the decision-making process related to policies in cacao-based agroforestry development in the forest park. Their suggestions/expectations were accepted, but there was no guarantee that they would be adopted/implemented by the forest park management. Placation can also be interpreted as merely support so that people feel heard and not left behind in designing and formulating policy related to the regulation of WAR GFP management.

Table 3. Level of community participation in WAR GFP Management according to Arnstein's Participation Ladder

\begin{tabular}{llll}
\hline Ladder of community participation & Score & Level of power distribution \\
\hline 8 & Citizen Control & $\underline{216}$ & The level of power at the \\
7 & Delegated power & $\underline{201}$ & community/Citizen power \\
6 & Partnership & $\underline{185}$ & \\
\hline 5 & Placation & $\underline{170}$ & $\underline{\text { Justification for saying }}$ \\
4 & Consultation & $\underline{154}$ & “yes"/ Tokenism \\
3 & Deliver information & $\underline{139}$ & \\
\hline 2 & Therapy & $\underline{123}$ & Non-Participation \\
1 & Manipulation & $\underline{108}$ & \\
\hline
\end{tabular}

Participation is an essential first step in implementing a policy, but due to limited time, funds, and target demands that must be achieved, it often has to be reduced to technical instruments only. Consequently, the voice and needs of the community are ignored. In this condition, community participation only reached the "placation" level. In addition, many studies stated that participatory approaches often ignore the dynamics of power and patterns of interaction between individuals with very diverse social structures. This has implications for controlling information and access to resources by groups with more access and power (Cleaver, 1999; Sugiana, 2012; Daeli et al., 2017). Finally, how far the community can participate in program development is very much determined not only by the willingness and the ability of the community to participate, but it is also influenced by the willingness of the program initiator/planners to provide space and enabling conditions through negotiation, communication, and to bring forward the different needs of all actors in program development (Thwala, 2010).

\subsection{Cacao Production}

Cacao yield was calculated based on the plant class density. There was a very high variation of cacao tree density found in the cacao-based agroforestry systems at the research site, between 30 and 2,000 plants per ha. Therefore, we classified the cacao density into four classes, namely 30-250, >250-500, >500-1,000 and >1,000-2,000 plants/ha. When calculating associated tree density according to the cacao tree density classification, we found that the associated tree density decreased with the increase of cacao density until the population of all trees reached 772 plants/ha. After that, cacao and associated tree density increased and reached nearly 2,500 plants/ha in total 
(Figure 4 and Table A2). These imply that the farmers planted various tree crops as many as possible to obtain additional yield and income. However, cacao yield will break even when the entire tree density has reached 1,253 plants/ha (719 cacao trees and 534 associated trees). After that, the increase of cacao yield was not proportional to cacao tree density.

Vaast \& Somarriba (2014) stated that farmers' reason to plant many tree crop species in cacao agroforestry systems was to earn additional income from diverse crops yield. The different harvest times of the other tree crops secured the farmers' income throughout the year; hence the farmers have seasonal, monthly, and weekly incomes. When comparing before and after farmers developed cacao-based agroforestry, there was a significant increase in land productivity. Before cacao-based Agroforestry development, the land was only planted with rice and/or secondary crops in monoculture with an average annual income of IDR $7,286,671$,- or US\$ 613.44 /ha (Barokah et al., 2014), while after cacao-based agroforestry development, the generated income was IDR 16,307,723,- or equal to US\$1,174.69/ha/year. Notaro et al. (2020) reported that the option for crop species and planting density in cacao agroforestry systems impacted the quantity and the economic value of the agricultural products sold and consumed by producers.

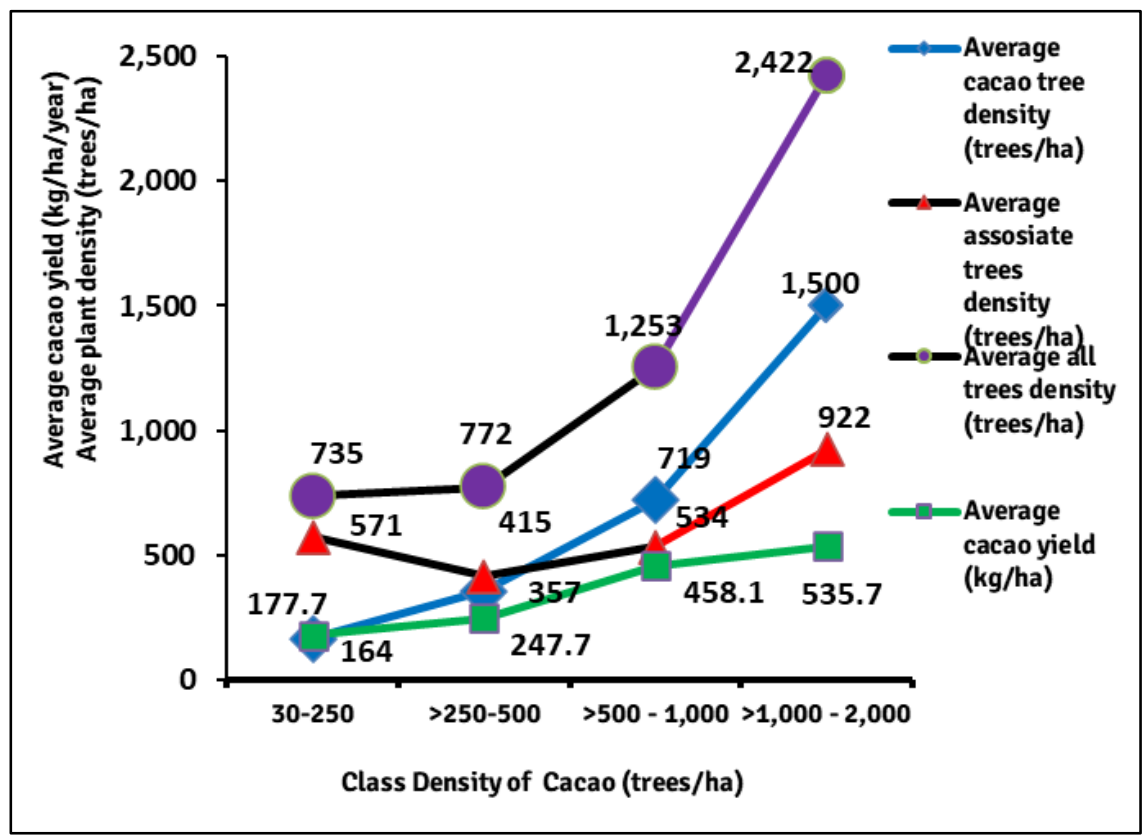

Figure 4. Cacao yield according to the plant class density at cacao-based agroforestry systems in WAR GFP, Lampung Province, Indonesia

The average cacao tree density at the cacao-based agroforestry systems was $554.2 \pm 434.2$ trees/ha, and the average cacao production in the form of dry cocoa beans was $367.4 \pm 357.9 \mathrm{~kg} / \mathrm{ha}$ (Table 4). This average cocoa beans production was relatively low compared to Indonesia National production reached $729 \mathrm{~kg} / \mathrm{ha}$ (Ministry of Agriculture, 2019a). However, besides cacao, many other products were obtained from the associated tree crops, such as durian fruit, candlenut, clove, and nutmeg, as 
substitutes for less cocoa production. It signifies that cacao agroforestry provides additional advantages such as products diversity as well as conservation of the species diversity and ecosystem services. Tetteh et al. (2018) recommended that for successful cocoa production, a shaded cacao agroforestry system must be encouraged to ensure biodiversity conservation, ecosystem services, and sustainable management of cacao farmlands.

On the other hand, Sonwa et al. (2014) emphasized that intensification of cacao agroforestry with a concentration on one or few species is seen as a manageable strategy because it is easier to cultivate the cacao trees with one/two associated tree species. The associated tree species selection can be matched with the aim of the cacao agroforestry options, such as conserving forest resources or earning income from nontimber forest products. However, the farmers plant many tree crop species to fulfill daily needs and meet the market demand. Low average cocoa bean productivity of cacaobased agroforestry systems at the research site, which was only about a half of Indonesia National Productivity, is since mean cacao tree density was only about a half of the average total tree crop density per ha (Table 4). Nevertheless, cocoa beans productivity from this cacao-based agroforestry system is still higher than cocoa productivity from cacao agroforestry in Cameroon, i.e., $206.9 \pm 207.3 \mathrm{~kg} / \mathrm{ha}$ (Essouma et al., 2020).

Table 4. Mean values for eight variables of cacao-based agroforestry systems at WAR GFP, Lampung Province, Indonesia

\begin{tabular}{cll}
\hline No. & Variable & Mean value \\
\hline 1 & Cacao tree density $($ trees ha & -1 \\
2 & Cacao yield $\left(\mathrm{kg} \mathrm{ha}^{-1}\right)$ & $554.2 \pm 434.2$ \\
3 & Associated food tree crop density $\left(\right.$ trees ha $\left.^{-1}\right)$ & $367.4 \pm 357.9$ \\
4 & Associated cash tree crop density $\left(\right.$ trees ha $\left.^{-1}\right)$ & $319.3 \pm 333.6$ \\
5 & Associated forest tree density $($ trees ha & -1 \\
6 & All associated living tree density $\left(\right.$ trees ha $\left.^{-1}\right)$ & $291.7 \pm 403.0$ \\
7 & Total tree density (trees ha $\left.{ }^{-1}\right)$ & $4.0 \pm 10.3$ \\
8 & Average number of tree species per each farmer's farm land & $615.1 \pm 470.2$ \\
\hline
\end{tabular}

\subsection{Main Commodities of Cacao-based Agroforestry Systems and Their Contribution to the Local and Regional Production}

From 37 plant species planted at the cacao-based agroforestry systems (excluding forest tree species), 14 plant species possessed substantial yield and contributed to the farmers' livelihood (Table 5). The production of each species was calculated for all respondents for the whole year. Most respondents (95.1\%) harvested cocoa as the primary commodity, while the other $4.9 \%$ of respondents did not harvest cocoa since they only had immature cacao plants. Other commodities harvested by many respondents $(72.1 \%)$ were candlenut and durian fruits, while commodities planted and harvested by the smallest respondents (13.1\% and 9.8\%) were avocado and areca nut. Production of the 14 primary commodities of cacao-based agroforestry systems ranged from $647 \mathrm{~kg}$ to 47.190 tons per year. The two highest productions were rubber and cacao, and the smallest production was contributed by clove. Besides that, there were products that were used for farmers' own consumption and it is difficult to calculate the values. However, this provided household savings and food security since most of the products are edible. This strengthens Cerda et al. (2014) study in five Central American countries showing that plants and trees in the shade canopy of cacao agroforestry systems produce diverse fruits and timber that can provide high value for domestic 
consumption at low cash costs, contribute to family savings, and assure food security.

Table 5. Production of 14 main commodities of cacao-based agroforestry systems in WAR GFP, Lampung Province, Indonesia

\begin{tabular}{|c|c|c|c|c|c|c|c|}
\hline \multirow[b]{2}{*}{ No } & \multicolumn{2}{|c|}{ Species } & \multirow[b]{2}{*}{ Product } & \multirow{2}{*}{$\begin{array}{c}\text { Coverage } \\
\text { harvested } \\
\text { area (ha) }\end{array}$} & \multirow{2}{*}{$\begin{array}{c}\text { Number of } \\
\text { harvested } \\
\text { plants } \\
\text { (trees) }\end{array}$} & \multirow{2}{*}{$\begin{array}{l}\text { Number of } \\
\text { respondents }\end{array}$} & \multirow{2}{*}{$\begin{array}{c}\text { Yield } \\
\text { (ton/ye } \\
\text { ar) }\end{array}$} \\
\hline & $\begin{array}{l}\text { Common } \\
\text { Name }\end{array}$ & $\begin{array}{l}\text { Scientific } \\
\text { Name }\end{array}$ & & & & & \\
\hline 1 & Cacao & $\begin{array}{l}\text { Theobroma } \\
\text { cacao }\end{array}$ & $\begin{array}{c}\text { Cocoa } \\
\text { dry } \\
\text { beans }\end{array}$ & 74.24 & 41,880 & 58 & 25.694 \\
\hline 2 & Candle nut & $\begin{array}{l}\text { Aleurites } \\
\text { moluccana }\end{array}$ & $\begin{array}{c}\text { Beans' } \\
\text { meat }\end{array}$ & 72.87 & 992 & 44 & 7.475 \\
\hline 3 & Durian $^{*}$ & $\begin{array}{l}\text { Durio } \\
\text { zibethinus }\end{array}$ & $\begin{array}{l}\text { Fresh } \\
\text { fruits }\end{array}$ & 70.68 & 872 & 44 & 16.112 \\
\hline 4 & Petai $^{* *}$ & $\begin{array}{l}\text { Parkia } \\
\text { speciosa }\end{array}$ & $\begin{array}{l}\text { Fresh } \\
\text { pods }\end{array}$ & 49.68 & 344 & 34 & 10.455 \\
\hline 5. & Jengkol & $\begin{array}{l}\text { Archidendron } \\
\text { pauciflorum }\end{array}$ & $\begin{array}{l}\text { Fresh } \\
\text { fruits' }\end{array}$ & 44.81 & 210 & 26 & 9.210 \\
\hline 6. & Melinjo & $\begin{array}{l}\text { Gnetum } \\
\text { gnemon }\end{array}$ & $\begin{array}{l}\text { Fresh } \\
\text { fruits }\end{array}$ & 38.87 & 1,046 & 26 & 9.939 \\
\hline 7. & Rubber & $\begin{array}{l}\text { Hevea } \\
\text { brasiliensis }\end{array}$ & $\begin{array}{l}\text { Dry } \\
\text { latex }\end{array}$ & 28.00 & 11,560 & 23 & 47.190 \\
\hline 8. & Clove & $\begin{array}{l}\text { Syzygium } \\
\text { aromaticum }\end{array}$ & $\begin{array}{l}\text { Dry } \\
\text { fruit }\end{array}$ & 37.22 & 441 & 21 & 0.647 \\
\hline 9 & Nutmeg & $\begin{array}{l}\text { Myristica } \\
\text { fragrans }\end{array}$ & $\begin{array}{c}\text { Dry } \\
\text { beans }\end{array}$ & 30.25 & 546 & 16 & 0.915 \\
\hline 10. & Coffee & Coffea arabica & $\begin{array}{c}\text { Dry } \\
\text { beans }\end{array}$ & 22.40 & 16,600 & 15 & 6.195 \\
\hline 11. & Banana & Musa sp & $\begin{array}{l}\text { Fresh } \\
\text { fruits }\end{array}$ & 20.31 & 1,875 & 15 & 16.250 \\
\hline 12. & Coconut $^{*}$ & $\begin{array}{l}\text { Cocos } \\
\text { nucifera }\end{array}$ & $\begin{array}{l}\text { Fresh } \\
\text { fruits }\end{array}$ & 17.18 & 101 & 12 & 5.102 \\
\hline 13. & Avocado & $\begin{array}{l}\text { Persea } \\
\text { americana }\end{array}$ & $\begin{array}{l}\text { Fresh } \\
\text { fruits }\end{array}$ & 14.00 & 73 & 8 & 1.800 \\
\hline 14. & Areca nut & $\begin{array}{l}\text { Areca } \\
\text { catechu }\end{array}$ & $\begin{array}{c}\text { Dry } \\
\text { beans }\end{array}$ & 9.66 & 309 & 6 & 1.350 \\
\hline
\end{tabular}

Remark: Total respondents: 61 . Total coverage area: 91.43 ha. ${ }^{*}$ Assuming 1 fruit $=1 \mathrm{~kg}$.

${ }^{* *}$ Assuming 10 pods $=1 \mathrm{~kg}$

Contributions of 14 primary commodities from cacao-based agroforestry systems in WAR GFP to local (Pesawaran Regency) and regional (Lampung Province) productions (Table 6) were calculated by converting the total production obtained from 61 respondents with a total area of 91.43 ha to all tenants in the WAR GFP who practiced the cacao-based agroforestry systems, covering 35 forest farmer group alliances with a total area of 8,880 ha. The conversion result was then compared with the agricultural production of Pesawaran Regency and Lampung Province.

Table 6. Contribution of 14 main commodities from cacao-based agroforestry systems at WAR Grand Forest Park to local and regional production

\begin{tabular}{|c|c|c|c|c|c|c|c|}
\hline No & Commodity & $\begin{array}{c}\text { Respondent's } \\
\text { Production } \\
\text { (ton/year)* }\end{array}$ & $\begin{array}{l}\text { Production } \\
\text { from all } \\
\text { Agroforestry } \\
\text { at WAR GFP } \\
\text { (ton/year) }\end{array}$ & $\begin{array}{c}\text { Production of } \\
\text { Pesawaran } \\
\text { Regency } \\
\text { (ton/year)** }\end{array}$ & $\begin{array}{l}\text { Production of } \\
\text { Lampung } \\
\text { Province } \\
\text { (ton/year) }\end{array}$ & $\begin{array}{l}\text { Contribution to } \\
\text { Pesawaran } \\
\text { Regency } \\
\text { Production (\%) }\end{array}$ & $\begin{array}{c}\text { Contribution } \\
\text { to Lampung } \\
\text { Province } \\
\text { Production } \\
(\%)\end{array}$ \\
\hline 1 & Cacao & 25.694 & $2,495.5$ & 28,509 & 58,251 & 8.75 & 4.28 \\
\hline 2 & $\begin{array}{l}\text { Candle } \\
\text { nut }\end{array}$ & 7.475 & 726.0 & $\mathrm{~N} / \mathrm{A}$ & N/A & - & - \\
\hline 3 & Durian & 16.112 & $1,564.8$ & 9,346 & 29,683 & 16.74 & 5.27 \\
\hline
\end{tabular}




\begin{tabular}{|c|c|c|c|c|c|c|c|}
\hline No & Commodity & $\begin{array}{c}\text { Respondent's } \\
\text { Production } \\
\text { (ton/year)* }^{*}\end{array}$ & $\begin{array}{l}\text { Production } \\
\text { from all } \\
\text { Agroforestry } \\
\text { at WAR GFP } \\
\text { (ton/year) }\end{array}$ & $\begin{array}{c}\text { Production of } \\
\text { Pesawaran } \\
\text { Regency } \\
\text { (ton/year) }^{* *}\end{array}$ & $\begin{array}{l}\text { Production of } \\
\text { Lampung } \\
\text { Province } \\
\text { (ton/year) }\end{array}$ & $\begin{array}{l}\text { Contribution to } \\
\text { Pesawaran } \\
\text { Regency } \\
\text { Production (\%) }\end{array}$ & $\begin{array}{l}\text { Contribution } \\
\text { to Lampung } \\
\text { Province } \\
\text { Production } \\
\text { (\%) }\end{array}$ \\
\hline 4 & Petai & 10.455 & 101.5 & 1,071 & 13,794 & 9.48 & 0.74 \\
\hline 5. & Jengkol & 9.210 & 894.5 & N/A & $12,989.6$ & - & 6.88 \\
\hline 6. & Melinjo & 9.939 & 965.3 & 2,399 & 12,170 & 40.24 & 7.93 \\
\hline 7. & Rubber & 47.190 & $4,583.2$ & N/A & $174,077^{b}$ & - & 2.63 \\
\hline 8. & Clove & 0.647 & 62.8 & $163.9^{a}$ & $1,668^{c}$ & 38.32 & 3,76 \\
\hline 9 & Nutmeg & 0.915 & 88.8 & $99^{d}$ & $454^{d}$ & 89.70 & 19.60 \\
\hline 10. & Coffee & 6.195 & 601.7 & 1,424 & 110,570 & 42.25 & 0.54 \\
\hline 11. & Banana & 16.250 & $1,578.2$ & 414,666 & $1,438,559$ & 0.38 & 0.11 \\
\hline 12. & Coconut & 5.102 & 495.5 & 14,902 & 85,918 & 3.33 & 0.58 \\
\hline 13. & Avocado & 1.800 & 174.8 & 1,800 & 13,677 & 9.71 & 1.28 \\
\hline 14. & Areca nut & 1.350 & 131,1 & N/A & N/A & - & - \\
\hline
\end{tabular}

Remark: *Total respondents: 61; Total coverage area: 91.43 ha. ** : BPS-Statistics of Pesawaran Regency (2020). ***: BPS-Statistics of Lampung Province (2019). ${ }^{*}$ : BPS-Statistics of Pesawaran Regency (2018). ${ }^{b}$ : Ministry of Agriculture (2019b). ${ }^{c}$ : Ministry of Agriculture (2019c). ${ }^{d}$ : Ministry of Agriculture (2019d). N/A: No data available

Table 6 shows that among 14 primary commodities from cacao-based agroforestry systems practiced in WAR GFP, nutmeg production has the highest contribution $(89.70 \%)$ to local (Pesawaran Regency) production. Cacao, however, has a lower contribution (8.75\%) compared to the other six commodities. For contribution to regional (Lampung Province) production, nutmeg also has the highest contribution $(19.60 \%)$, followed by melinjo (7.93\%), and the other three commodities (jengkol, durian, and cacao).

This research result indicates that 14 main commodities cultivated at cacaobased agroforestry systems at WAR GFP have important contribution, especially to the local (district level) production. Some commodities contribute more than $40 \%$ (nutmeg, coffee, melinjo) to the district production. This implies that commodities from cacaobased agroforestry systems can potentially be developed and scaled up at other forest areas under a community-based forest management scheme. Cerda et al. (2014) reported that the contribution of agroforestry products from cacao-based agroforestry system to family income is similar to or higher than that of cocoa beans, and it becomes as important as the main crop for the farmer livelihoods. In line with that, income from cacao in the cacao-based agroforestry systems at WAR GFP does not contribute the highest to the family's income. Despite all, this commodity suits well with the forest ecosystem as the shade tolerant plant as it needs shade to grow and produce yield. Therefore, cacao is suitable for cultivating with other higher tree crop species in multicropping systems like agroforestry. In addition, the cacao canopy and its biomass are sufficient to keep the forest cover always green.

\subsection{Farmer's Income and Contribution of the Cacao-based Agroforestry System to the Local Economy}

\subsubsection{Farmer's income}

Besides optimizing land use, the cacao-based agroforestry system was also intended for product diversification and income security. It was expected that when one product's price went down, it could be compensated for by another product whose price went up. Many studies signify that agroforestry is significant in improving rural community livelihoods, especially for increasing income and crop yield and improving 
the health and nutrition of the farmers (Ndalama et al., 2015; Chakraborty et al., 2015; Hanif et al., 2018).

Analysis of the respondents' income shows that income contribution from cacaobased agroforestry systems at WAR GFP is quite significant; it reaches $75.63 \%$ of the total family income (Figure 5). This contribution is much higher than income from agroforestry of cacao and nyatoh (Palaquium rostratum) in Sulawesi (46.7\%) (Jumiyati et al., 2018) or cacao agroforestry developed in Bocas del Toro, Panama, Central America (19\%) (Niehaus, 2011).

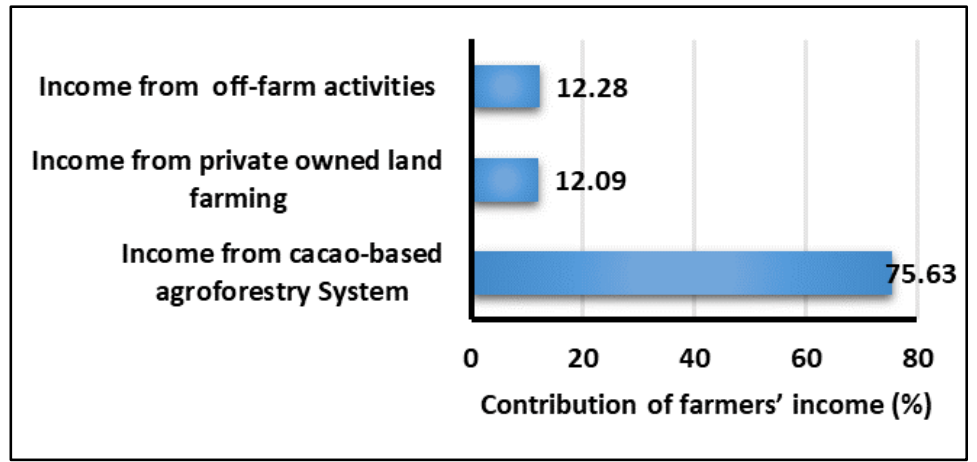

Figure 5. The contribution of income from cacao-based agroforestry system at WAR GFP to the total farmer's income

The high contribution of income gained from cacao-based agroforestry system at WAR GFP to total family income indicated that farming in the WAR GFP was the main source of farmers' livelihood. Meanwhile, farming on privately owned land and off-farm activities were considered additional sources of income. This is logical since land sizes of each farming activity are different, where the mean farmland size at the WAR GFP is nearly 10 times of average farmland size on farmers' own land. This high contribution was much higher than the contribution of agroforestry practiced in Parungpanjang West Java, which was only $15.5 \%$ of farmers' total income (Desmiwati et al., 2021). The situation was very much different from Niehaus' (2011) study in Bocas del Toro, Panama, Central America, which revealed that income generated from cacao agroforestry was more considered as additional income as most income (52\%) was generated from external sources and from other farming activities (29\%). A study by Cerda et al. (2014) indicated that the main contribution of agroforestry to small farmers' families was generating both cash incomes and products that were mainly for domestic consumption. As previously explained, farming activities in WAR GFP were carried out by planting various fruit species and tree crops in one land unit. Growing a variety of crops was a farmer's strategy for risk management. Rapsomanikis (2015) also confirmed that farmers having limited access to markets tend to plant various crops aiming not only for achieving better diets but also as a risk management strategy to stabilize their income, in case of price shocks, crop failure due to pest and disease attack and other risks. Other studies showed that besides considering economic benefit, the main reason for farmers to plant fruit trees was to get fruit for their own consumption (Hanif et al., 2018) or to optimize the use of limited land for highest income (Montenegro et al., 2018). 
In cacao-based agroforestry system at WAR GFP, fruit and tree crops were planted and maintained using the shared production costs (Table 7). Workers from within the family generally dominate the labor used for cacao-based agroforestry system. In this farm analysis, production costs incurred include the cost of seeds, fertilizer, labor, and equipment, but labor calculated as the cost was that coming from outside the family, which was mainly spent for harvesting activities. This was different from cacao farmers in Central America, where most of them did not use any inputs (pesticides or fertilizers). Hence, the most significant cash cost was mainly for labor (Deheuvels et al., 2014). In WAR GFP if the cost calculation was carried out specifically for cacao cultivation, the total cost that farmers must incur was $55.42 \%$ of the total revenue. Meanwhile, if the farm analysis was carried out for all plants cultivated (14 primary commodities), the total cost incurred was $33.19 \%$ of their total revenue, showing that the farming costs incurred were allocated primarily for the cultivation of cacao, which was considered as the main farming commodity in WAR GFP. The decrease in production cost in cacaobased agroforestry compared to monoculture cacao cultivation implies that cultivating other crops will provide additional revenue while reducing production costs. This finding confirms the study by Jumiyati et al. (2018) in Central Sulawesi, showing that agroforestry cacao development with nyatoh farming can significantly increase the revenue and reduce production cost by $25 \%$.

Table 7. Average revenue, production cost and farmers' income from cacao-based agroforestry system in WAR GFP

\begin{tabular}{lrrrr}
\hline \multirow{2}{*}{ Description } & \multicolumn{2}{c}{ Total respondent ${ }^{*}\left(\right.$ IDR/year) ${ }^{\star *}$} & \multicolumn{2}{c}{ Average $\left(\right.$ IDR/HH/year) ${ }^{\star *}$} \\
\cline { 2 - 5 } & \multicolumn{1}{c}{ Cacao only } & \multicolumn{1}{c}{ Cacao agroforestry } & \multicolumn{1}{c}{ Cacao only } & Cacao agroforestry \\
\hline Revenue & $1,075,305,000$ & $2,231,651,000$ & $17,627,951$ & $36,584,443$ \\
Cost & $595,892,400$ & $740,635,900$ & $9,768,728$ & $12,141,572$ \\
Income & $479,412,600$ & $1,491,015,100$ & $7,859,223$ & $24,442,871$ \\
\hline
\end{tabular}

*Total respondents: 61; Total coverage area: 91.43 ha

**US\$ $1 \approx \operatorname{IDR} 13,882.62$

The largest allocation of production costs was mainly for the purchase of seeds and fertilizers for production intensification. Small farmers seem to use them more intensively, as commonly found in sub-Saharan areas where smallholders use the two more intensively than larger farmers (Rapsomanikis, 2015). However, it is different from Kaplale (2011) findings, who found that the largest allocation of farm costs incurred was for labor costs. To analyze whether there was a relationship between the size of cultivated land of cacao agroforestry and the optimum land management, we classified the cultivated land size into three groups $(<0.5 \mathrm{Ha}$; $0.5-2 \mathrm{Ha} ;>2 \mathrm{Ha})$. We adopted the farmland classification following Kaplale (2011), who classified farmers based on the size of farm area, i.e., a. Small farmer group (<0.5 Ha); b. Medium farmer group (0.5 - 2 $\mathrm{Ha}$ ); c. Large farmer group (> $2 \mathrm{Ha}$ ); and d. Landless farmer group. Figure 6 shows the increase in farmers' income in WAR GFP based on cultivated land size from cocoa yield only, fruit and tree crops yield of main commodities (13 commodities excluding cacao), and from the total yield (14 main commodities). The increase in income is in line with the increased cultivated land size. This is in line with the study of Desmiwati et al. (2021), which also confirmed that land size was one of the agroforestry factors that influenced farmers' income. Farmers with larger agroforestry land areas have more opportunities to increase their household income. 
However, if we look at the average income earned by the farmers in each land class, which is then converted to the same land size of $1 \mathrm{Ha}$ to evaluate the effectiveness of land management in each class, it turns out that the farmers' income in the smallest land size class was the largest compared to the other two classes. This shows that the smaller land area encourages farmers to be more intensive and efficient in utilizing the land. This is in accordance with the study carried out in several developing countries, which revealed that crop yields per hectare (measured in \$) on smallholder farms were much higher than those of large farms. One example was from the United Republic of Tanzania, where a farmer cultivated less than 1 ha (average 0.9 ha) produced food products worth $\$ 780$ per hectare, compared to the $\$ 281$ per hectare produced by a larger farmer cultivating 4.1 ha (Rapsomanikis, 2015). The limited cultivated land encourages farmers to do their best to make optimal use of the land. Therefore, each unit of input invested can produce larger output (Figure 7).

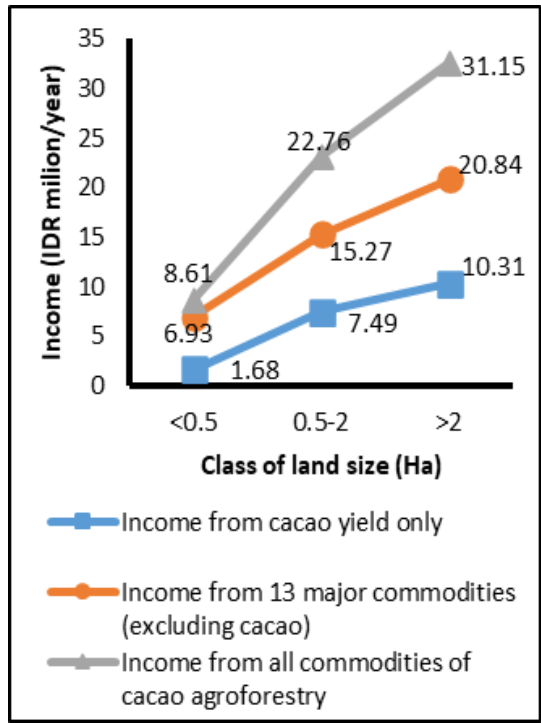

Figure 6. Farmers' income from average land cultivation at three land size classes

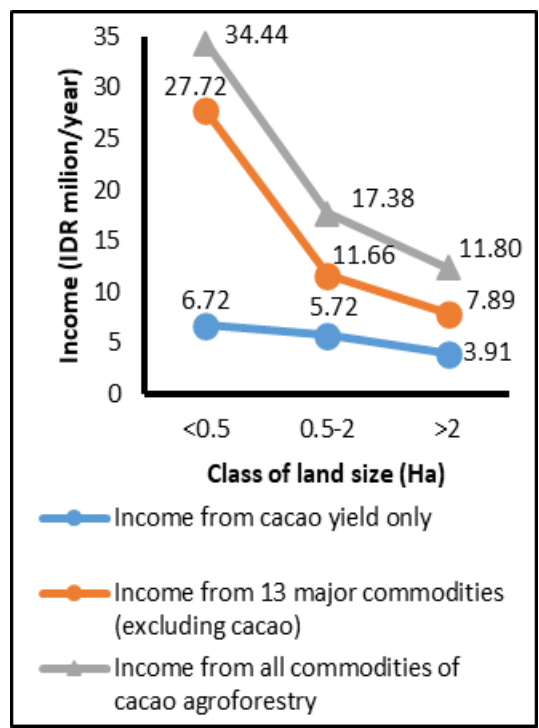

Figure 7. Farmers' income from $1 \mathrm{Ha}$ area of cultivation at three land size classes

\subsubsection{Contribution of cacao-based agroforestry practices in conservation forest area to local economy}

To analyze the proportion of income earned from cacao yield at cacao-based agroforestry system that can be contributed to: a. farmers' income from cacao-based agroforestry system at WAR GFP; b. total farmers' income from on-farm activities (both in WAR GFP area and on farmers' own-land); and c. total farmers' income from both onfarm and off-farm activities, we also made three classifications of cultivated land. With these three classifications ( $<0.5 \mathrm{Ha}$; $0.5-2 \mathrm{Ha}$; $>2 \mathrm{Ha}$ ), we also evaluated whether there is a relationship between the size of cultivated land and the proportion of income that could be obtained from cocoa-based agroforestry development. Figure 8 shows that the wider the cacao agroforestry, the greater proportion of income from cacao yield that can be contributed to farmers' income from cacao agroforestry practice in WAR 
GFP; to farmers' income gained from on-farm activities (both in WAR GFP area and on farmers' own-land); to total farmers' income (on-farm and off-farm activities).

Nevertheless, if we look at the average income earned by the farmers from cacao cultivation in each land class, which is then converted to the same area of 1 hectare to see the effectiveness of land management in each class, it turns out that the proportion of income earned from cacao cultivation that can be contributed in the smallest land size class is the largest compared to the other two classes. This once again verifies that the smaller land area encourages farmers to be more intensive and efficient in cacao cultivation; hence, each input unit can generate greater output (Figure 9).

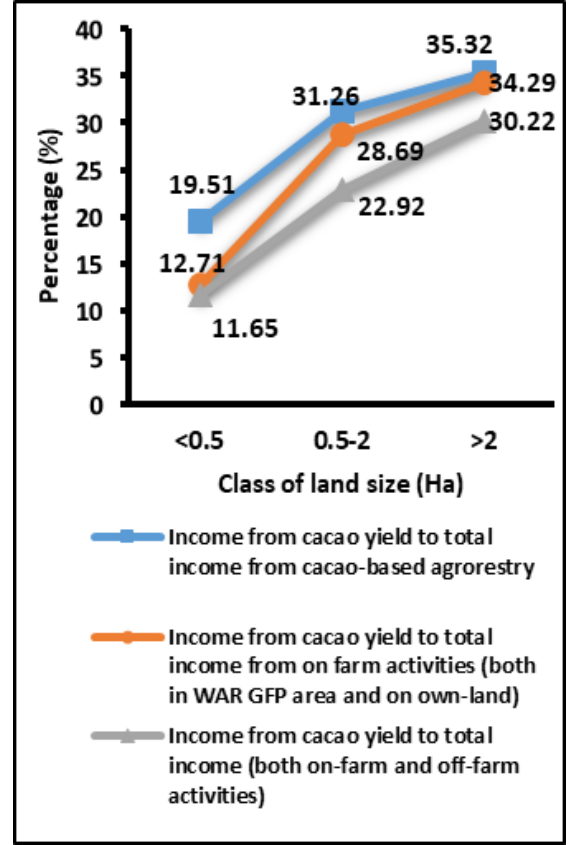

Figure 8. Income contribution from cacao yield at three land size classes

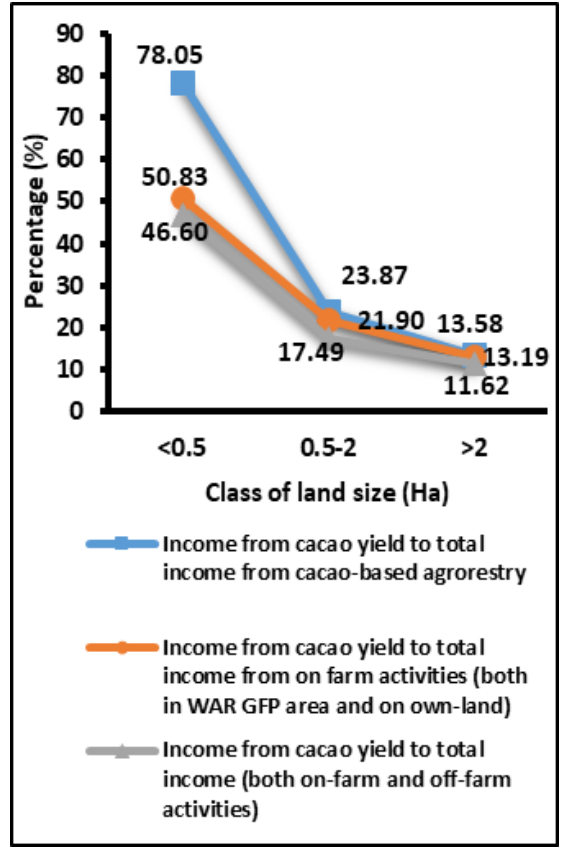

Figure 9. Income contribution from $1 \mathrm{Ha}$ area of cacao yield at three land size classes

Next, we analyzed how much actually income earned from cacao-based agroforestry systems in WAR GFP area contributed to the Gross Domestic Product (GDP) of Pesawaran District. To calculate it, we extrapolated the income obtained from cacao agroforestry systems in the study site covering a total area of 91.43 hectares to the total area of agroforestry developed in WAR GFP $(8,880 \mathrm{Ha})$ and then compared it with the GDP of Pesawaran District. The results showed that the contribution of income from cacao-based agroforestry system at all WAR GFP area $(8,880 \mathrm{Ha})$ to GDP of Pesawaran District is $0.95 \%$ (Table 8 ). Although it is relatively small, land utilization in WAR GFP has become a solution for the continued occupation of WAR GFP by its forest surrounding community. 
Table 8. Income contribution from cacao-based agroforestry systems at WAR GFP to GDP of Pesawaran District

\begin{tabular}{lcccc}
\hline \multicolumn{1}{c}{ Description } & $\begin{array}{c}\text { Total } \\
\text { area } \\
(\mathrm{Ha})\end{array}$ & $\begin{array}{c}\text { Total Income gained } \\
\text { (IDR/year) }\end{array}$ & $\begin{array}{c}\text { GDP of } \\
\text { Pesawaran } \\
\text { Regency }) \\
(\times \text { IDR 1000,000) }\end{array}$ & $\begin{array}{c}\text { Contribution to } \\
\text { GDP of } \\
\text { Pesawaran } \\
\text { Regency (\%) }\end{array}$ \\
\hline $\begin{array}{l}\text { Area of cacao-based } \\
\begin{array}{l}\text { Agroforestry in the } \\
\text { research site }\end{array}\end{array}$ & 91.43 & $1,491,015,100$ & & 0.01 \\
\cline { 1 - 3 } $\begin{array}{l}\text { Area of agroforestry } \\
\text { developed in WAR GFP }\end{array}$ & 8,880 & $144,812,578,891$ & $15,231.77$ & 0.95 \\
\hline
\end{tabular}

*(Badan Pusat Statistik Kabupaten Pesawaran, 2019)

To evaluate whether the income obtained from cacao-based agroforestry systems at WAR GFP can fulfil the households' basic needs, we used several criteria, including minimum wage rate of Pesawaran District and Lampung Province, the National Poverty Line and the Poverty Line set by the World Bank (Table 9).

Table 9. Comparison of income earned from cacao-based agroforestry system to fulfil household's basic needs

\begin{tabular}{|c|c|c|c|c|c|}
\hline Description & $\begin{array}{l}\text { Income from } \\
\text { cacao-based } \\
\text { agroforestry } \\
\text { systems } \\
\text { (IDR) }\end{array}$ & $\begin{array}{l}\text { Minimum } \\
\text { wage rate of } \\
\text { Pesawaran } \\
\text { Regency } \\
\text { IDR 69,156 } \\
\text { /HH/day*) }\end{array}$ & $\begin{array}{c}\text { Minimum wage } \\
\text { rate of } \\
\text { Lampung } \\
\text { Province } \\
\text { IDR } 69,156 \\
\text { /HH/day*) }\end{array}$ & $\begin{array}{c}\text { National Poverty } \\
\text { line**) } \\
\text { IDR13,374/capita } \\
\text { /day }\end{array}$ & $\begin{array}{c}\text { Poverty line of } \\
\text { World } \\
\text { Bank***) } \\
\text { US\$1.9/capita/ } \\
\text { day }\end{array}$ \\
\hline $\begin{array}{l}\text { Per HH per } \\
\text { day }\end{array}$ & 69,237 & $\checkmark$ & $\checkmark$ & - & - \\
\hline $\begin{array}{l}\text { Per capita } \\
\text { per } \\
\text { day }^{* * * *} \text { ) }\end{array}$ & 23,079 & - & - & $\checkmark$ & $x$ \\
\hline
\end{tabular}

The results in Table 9 shows that the income obtained from cacao-based agroforestry systems has been able to meet farmers' needs compared to the national poverty line criteria. However, it is still under those set by the World Bank. Compared to the minimum wage levels for both Pesawaran Regency and Lampung Province, the income obtained from agroforestry development in WAR GFP is also higher. This corroborates that the development of cacao-based agroforestry in WAR GFP has a significant role in improving household financial status, as Ndalama et al. (2015) stated that products generated from agroforestry trees serve as a source of household income. In addition, agroforestry products also function as safety nets for rural households and contribute as a significant source of income if produced and managed well (Kalaba et al., 2010; Chakraborty et al., 2015). According to Direktorat Jenderal Perkebunan (2017), the minimum land size for a farmer for cultivating cacao to fulfill family needs and develop farming sustainably is 2.47 ha. This minimum cacao farm size is much broader than the average area of cacao agroforestry in WAR GFP, which is only 1.5 ha. This proves that although the size of cacao farmland in the WAR GFP is not wide, it can contribute to a decent income for farmers since the cacao cultivation is carried out using agroforestry systems that combine several types of plants together. 


\section{CONCLUSION}

Small scale cacao-based agroforestry systems developed in Wan Abdul Rachman Grand Forest Park (WAR GFP) were traditionally managed based on farmers' hereditary knowledge. The agroforestry systems comprised 56 plant species, dominated by cacao trees and mixed with other tree crops and forest trees with an average tree density of $1,169.3 \pm 668.3$ trees/ha. Cacao yield was affected by the cacao and the associated tree density. Average cacao production at the cacao-based agroforestry was relatively low, i.e., $367.4 \pm 357.9 \mathrm{~kg} / \mathrm{ha}$. Fortunately, there were 13 other main commodities produced by the associated tree crops. Some commodities contributed more than $40 \%$ of the regency production. The difference in harvesting time of the associated tree crops secured the farmers' income throughout the year.

Community's involvement in developing cacao-based agroforestry in WAR GFP has only reached the "Placation" or level 5 of Arnstein's participation ladder. "Placation" implies that the communities are solely granted limited opportunities to participate or influence the process, and their participation is tokenistic.

Income obtained from cacao-based agroforestry systems at WAR GFP contributed significantly $(75.63 \%)$ to the total households' income, which was higher than the stipulated minimum wage levels for Pesawaran Regency and Lampung Province. Furthermore, it can meet the basic needs of farmers and has already exceeded the poverty line at the national level.

Cacao-based agroforestry is a promising alternative for resolving land use conflicts in areas characterized by land scarcity with dense populations. It can also become a model for resolving the decrease in the quality of agricultural land resources in many tropical countries.

\section{Appendix A1}

Table A1. Detailed description of plants characteristics of cacao-based agroforestry systems at WAR GFP, Lampung Province, Indonesia

\begin{tabular}{|c|c|c|c|c|c|}
\hline \multirow{2}{*}{ No. } & \multicolumn{2}{|c|}{ Type of plant/species } & \multicolumn{3}{|c|}{ Number of Plants } \\
\hline & Common name & Scientific name & Productive & Un-productive & Total \\
\hline I & Food Tree crop & & & & \\
\hline 1 & Cacao & Theobroma cacao & 41,880 & 2,190 & 44,070 \\
\hline 2 & Candle nut & $\begin{array}{l}\text { Aleurites } \\
\text { moluccana }\end{array}$ & 992 & 446 & 1,438 \\
\hline 3 & Durian & Durio zibethinus & 872 & 1,296 & 2,168 \\
\hline 4 & Petai & Parkia speciosa & 344 & 599 & 943 \\
\hline 5 & Jengkol & $\begin{array}{l}\text { Archidendron } \\
\text { pauciflorum }\end{array}$ & 210 & 564 & 774 \\
\hline 6 & Gnetum & Gnetum gnemon & 1,046 & 91 & 1,137 \\
\hline 7 & Clove & $\begin{array}{l}\text { Syzygium } \\
\text { aromaticum }\end{array}$ & 441 & 1,521 & 1,962 \\
\hline 8 & Nutmeg & Myristica fragrans & 546 & 2,597 & 3,143 \\
\hline 9 & Coffee & Coffea arabica & 16,600 & 1,600 & 18,200 \\
\hline 10 & Banana & Musa sp. & 1,875 & 374 & 2,249 \\
\hline 11 & Coconut & Cocos nucifera & 101 & 62 & 163 \\
\hline 12 & Avocado & Persea americana & 73 & 128 & 201 \\
\hline 13 & Jackfruit & $\begin{array}{l}\text { Artocarpus } \\
\text { heterophylla }\end{array}$ & 76 & 25 & 101 \\
\hline 14 & Duku & $\begin{array}{l}\text { Lansium } \\
\text { domesticum }\end{array}$ & 16 & 42 & 58 \\
\hline 15 & Mango & Mangifera indica & 9 & 6 & 15 \\
\hline 16 & Sugar palm & Arenga pinnata & 11 & 9 & 20 \\
\hline 17 & Breadfruit & Artocarpus altilis & 13 & 2 & 15 \\
\hline 18 & Rambutan & Nephelium & 12 & 0 & 12 \\
\hline
\end{tabular}

Murniati et al. (2022) 


\begin{tabular}{|c|c|c|c|c|c|}
\hline \multirow{2}{*}{ No. } & \multicolumn{2}{|c|}{ Type of plant/species } & \multicolumn{3}{|c|}{ Number of Plants } \\
\hline & Common name & Scientific name & Productive & Un-productive & Total \\
\hline & & lappaceum & & & \\
\hline 19 & Orange & Citrus sp. & 15 & 7 & 22 \\
\hline 20 & Lime & Cytrus hystrix & 27 & 1 & 28 \\
\hline 21 & Guava & Psidium guajava & 0 & 6 & 6 \\
\hline 22 & Sour sop & Annona muricata & 18 & 2 & 20 \\
\hline 23 & Moringa & Moringa oleifera & 7 & 100 & 107 \\
\hline \multirow[t]{2}{*}{24} & Asam kandis & $\begin{array}{l}\text { Garcinia } \\
\text { xanthochymus }\end{array}$ & 1 & 0 & 1 \\
\hline & Total & Species: 24 & 65,185 & 11,668 & 76,853 \\
\hline II & Cash tree crop & & & & \\
\hline 1 & Rubber & Hevea brasiliensis & 11,560 & 7,501 & 19,061 \\
\hline 2 & Cottonwoods & Ceiba pentandra & 130 & 14 & 144 \\
\hline \multirow[t]{2}{*}{3} & Areca nut & Areca catechu & 309 & 975 & 1,284 \\
\hline & Total & Species: 3 & 11,999 & 8,490 & 20,489 \\
\hline III & Forest Tree & & & & \\
\hline 1 & Medang & Litsea spp. & 0 & 41 & 41 \\
\hline 2 & Cempaka & Michelia champaca & 0 & 155 & 155 \\
\hline 3 & Sonokeling & Dalbergia latifolia & 0 & 8 & 8 \\
\hline 4 & Mahogany & $\begin{array}{l}\text { Swietenia } \\
\text { macrophylla }\end{array}$ & 0 & 10 & 10 \\
\hline 5 & Bayur & Pterospermum spp. & 0 & 12 & 12 \\
\hline 6 & Dadap & Erythrina variegata & 0 & 27 & 27 \\
\hline 7 & Pulai & Alstonia scholaris & 0 & 14 & 14 \\
\hline 8 & Jabon merah & $\begin{array}{l}\text { Antocephalus } \\
\text { macrophyllus }\end{array}$ & 0 & 5 & 5 \\
\hline 9 & $\begin{array}{l}\text { Kayu } \\
\text { kelompayan }\end{array}$ & $\begin{array}{l}\text { Antocephalus } \\
\text { cadamba }\end{array}$ & 0 & 2 & 2 \\
\hline 10 & $\begin{array}{l}\text { Kayu binong/ } \\
\text { tabu }\end{array}$ & $\begin{array}{l}\text { Tetrameles } \\
\text { nudiflora }\end{array}$ & 0 & 24 & 24 \\
\hline 11 & Kihiang/weru & Albizzia procera & 0 & 10 & 10 \\
\hline 12 & Kayu kembang & Pterocarpus indicus & 0 & 5 & 5 \\
\hline 13 & Kayu kondang & Ficus variegata & 0 & 5 & 5 \\
\hline 14 & Kayu dahu & $\begin{array}{l}\text { Dracontomelon } \\
\text { mangiferum }\end{array}$ & 0 & 5 & 5 \\
\hline 15 & Kayu gintung & Bischofia javanica & 0 & 2 & 2 \\
\hline 16 & Kayu kepayang & Pangium edule & 0 & 2 & 2 \\
\hline 17 & $\begin{array}{l}\text { Kayu } \\
\text { wuwingan }\end{array}$ & Antidesma bunins & 0 & 1 & 1 \\
\hline 18 & Sengon & $\begin{array}{l}\text { Falcataria } \\
\text { moluccana }\end{array}$ & 0 & 2 & 2 \\
\hline \multirow[t]{3}{*}{19} & Bamboo & Gigantochloaspp & 0 & 100 & 100 \\
\hline & Total & Species: 19 & 0 & 430 & 430 \\
\hline & Total I+II+III & Species: 46 & 77,184 & 20,588 & 97,772 \\
\hline IV & \multicolumn{5}{|c|}{ Undergrowth species } \\
\hline 1 & Chili & Capsicum sp & & & \\
\hline 2 & Java Chili & Piper retrofractum & & & \\
\hline 3 & Pepper & Piper nigrum & & & \\
\hline 4 & Vanilla & Vanilla planifolia & & & \\
\hline 5 & Taro & Colocasia esculenta & & & \\
\hline 6 & Spice: turmeric & Curcuma longa & & & \\
\hline 7 & Spice: ginger & Zingiber officinale & & & \\
\hline 8 & $\begin{array}{l}\text { Spice: } \\
\text { galangal }\end{array}$ & Alpinia galanga & & & \\
\hline 9 & $\begin{array}{l}\text { Spice: } \\
\text { cardamom }\end{array}$ & $\begin{array}{l}\text { Elettaria } \\
\text { cardamomum }\end{array}$ & & & \\
\hline 10 & Lemongrass & $\begin{array}{l}\text { Cymbopogon } \\
\text { citratus }\end{array}$ & & & \\
\hline & Total IV & Species: 10 & & & \\
\hline & Total I - IV & Species: 56 & & & \\
\hline
\end{tabular}


Remark: Total respondents: 61

Total coverage area: 91.43 ha

\section{Appendix A2}

Table A2. Cacao production according to cacao and the associated tree density of cacao-based agroforestry systems at WAR GFP, Lampung Province, Indonesia

\begin{tabular}{|c|c|c|c|c|c|}
\hline $\begin{array}{l}\text { Class of cacao tree } \\
\text { density (trees/ha) }\end{array}$ & $\begin{array}{c}\text { Cacao tree } \\
\text { density } \\
\text { (tress/ha) }\end{array}$ & $\begin{array}{l}\text { Associated } \\
\text { tree density } \\
\text { (trees/ha) }\end{array}$ & $\begin{array}{c}\text { Total tree } \\
\text { density } \\
\text { (trees/ha) }\end{array}$ & $\begin{array}{c}\text { Cacao } \\
\text { production } \\
(\mathrm{kg} / \mathrm{ha})\end{array}$ & $\begin{array}{l}\text { Number of } \\
\text { species }\end{array}$ \\
\hline \multirow[t]{7}{*}{$30-250(n=7)$} & 30 & 1,359 & 1,389 & 50.0 & 8.0 \\
\hline & 50 & 505 & 555 & 15.0 & 7.0 \\
\hline & 167 & 190 & 357 & 200.0 & 12.0 \\
\hline & 200 & 820 & 1,020 & 216.0 & 13.0 \\
\hline & 200 & 888 & 1,088 & 13.0 & 7.0 \\
\hline & 250 & 18 & 268 & 400.0 & 7.0 \\
\hline & 250 & 216 & 466 & 350.0 & 12.0 \\
\hline Average & 164 & 571 & 735 & 177.7 & 9.4 \\
\hline \multirow[t]{19}{*}{$>250-500(n=19)$} & 267 & 880 & 1,147 & 277.0 & 8,0 \\
\hline & 267 & 371 & 637 & 107.0 & 9.0 \\
\hline & 267 & 85 & 352 & 267.0 & 9.0 \\
\hline & 300 & 161 & 461 & 200.0 & 12.0 \\
\hline & 300 & 230 & 530 & 100.0 & 6.0 \\
\hline & 300 & 302 & 602 & 400.0 & 14.0 \\
\hline & 320 & 136 & 456 & 200.0 & 5.0 \\
\hline & 330 & 466 & 796 & 200.0 & 9.0 \\
\hline & 333 & 712 & 1,045 & 128.0 & 6.0 \\
\hline & 333 & 136 & 469 & 167.0 & 16.0 \\
\hline & 350 & 455 & 805 & 600.0 & 9.0 \\
\hline & 356 & 251 & 607 & 267.0 & 9.0 \\
\hline & 375 & 983 & 1,358 & 167.0 & 12.0 \\
\hline & 400 & 110 & 510 & 356.0 & 15.0 \\
\hline & 400 & 345 & 745 & 400.0 & 12.0 \\
\hline & 400 & 884 & 1,284 & 400.0 & 14.0 \\
\hline & 480 & 746 & 1,226 & 120.0 & 13.0 \\
\hline & 500 & 358 & 858 & 150.0 & 11.0 \\
\hline & 500 & 285 & 785 & 200.0 & 8.0 \\
\hline Average & 357 & 415 & 772 & 247.7 & 10.4 \\
\hline \multirow[t]{23}{*}{$>500-1,000(n=23)$} & 515 & 161 & 676 & 250.0 & 13.0 \\
\hline & 533 & 1,357 & 1,890 & 213.0 & 11.0 \\
\hline & 560 & 159 & 719 & 800.0 & 8.0 \\
\hline & 560 & 348 & 908 & 400.0 & 13.0 \\
\hline & 560 & 112 & 672 & 80.0 & 10.0 \\
\hline & 573 & 157 & 730 & 400.0 & 11.0 \\
\hline & 600 & 834 & 1,434 & $1,020.0$ & 8.0 \\
\hline & 600 & 1,408 & 2,008 & 800.0 & 11.0 \\
\hline & 600 & 234 & 834 & 333.0 & 12.0 \\
\hline & 650 & 358 & 1,008 & 250.0 & 12.0 \\
\hline & 667 & 92 & 759 & 533.0 & 8.0 \\
\hline & 667 & 135 & 801 & $1,000.0$ & 8.0 \\
\hline & 700 & 819 & 1,519 & 100.0 & 8.0 \\
\hline & 750 & 807 & 1,557 & 100.0 & 9.0 \\
\hline & 750 & 410 & 1,160 & 600.0 & 9.0 \\
\hline & 800 & 216 & 1,016 & 160.0 & 8.0 \\
\hline & 800 & 110 & 910 & 444.0 & 4.0 \\
\hline & 816 & 1,128 & 1,944 & $1,680.0$ & 12.0 \\
\hline & 833 & 813 & 1,646 & 178.0 & 8.0 \\
\hline & 1,000 & 1,019 & 2,019 & 213.0 & 9.0 \\
\hline & 1,000 & 1,141 & 2,141 & 27.0 & 6.0 \\
\hline & 1,000 & 282 & 1,282 & 556.0 & 8.0 \\
\hline & 1,000 & 180 & 1,180 & 400.0 & 11.0 \\
\hline Average & 719 & 534 & 1,253 & 458.1 & 9.4 \\
\hline
\end{tabular}

Murniati et al. (2022) 


\begin{tabular}{crrrrr}
\hline $\begin{array}{c}\text { Class of cacao tree } \\
\text { density (trees/ha) }\end{array}$ & $\begin{array}{c}\text { Cacao tree } \\
\text { density } \\
\text { (tress/ha) }\end{array}$ & $\begin{array}{c}\text { Associated } \\
\text { tree density } \\
\text { (trees/ha) }\end{array}$ & $\begin{array}{c}\text { Total tree } \\
\text { density } \\
\text { trees/ha) }\end{array}$ & $\begin{array}{c}\text { Cacao } \\
\text { production } \\
\text { (kg/ha) }\end{array}$ & $\begin{array}{c}\text { Number of } \\
\text { species }\end{array}$ \\
\hline$>1,000-2,000(n=9)$ & 1,067 & 1,715 & 2,781 & 160.0 & 10.0 \\
& 1,200 & 1,254 & 2,454 & $608 . .0$ & $7 . .0$ \\
& 1,333 & 1,147 & 2,480 & 213.0 & 8.0 \\
& 1,333 & 405 & 1,739 & 400.0 & 9.0 \\
& 1,563 & 670 & 2,232 & 600.0 & 6.0 \\
& 1,600 & 652 & 2,252 & 120.0 & 6.0 \\
& 1,600 & 852 & 2,452 & 640.0 & 6.0 \\
Average & 1,800 & 1,234 & 3,034 & 160.0 & 6.0 \\
& 2,000 & 374 & 2,374 & $1,920.0$ & 7.0 \\
\hline
\end{tabular}

Author Contributions: Murniati (MR.) and Sri Suharti (S.S.) conceptualized and designed the research; MR. and Minarningsih (MN.) performed the research; all contributors analyzed the data; S.S. verified the analytical methods; MR., S.S. and Irma Yeny (I.Y.) wrote the paper. All authors have read and agreed to the published version of the manuscript.

Conflicts of Interest: The authors declare no conflict of interest.

Acknowledgments: The authors would like to express gratitude to Centre for Forest Research and Development for providing funding for this research. The authors also thank the Management of Wan Abdul Rachman Grand Forest Park for facilitation during the study. Special thanks Sumarhani for her assistance in field data collection. Our appreciation and thanks go to all informants including agroforestry farmers at Cilimus and Bogorejo Villages who provided valuable data and information for this research.

\section{REFERENCES}

Alfandi, D., Qurniati, R., \& Febryano, I. G. (2019). Partisipasi masyarakat dalam pengelolaan mangrove. Jurnal Sylva Lestari, $7(1), \quad 30-41$. http://dx.doi.org/10.23960/jsl1730-41

Arnold, J. E. M. (1987). Economic considerations in agroforestry. In H. A. Steppler \& P. K. R. Nair (Eds.), Agroforestry: a decade of development (pp. 173-190). Nairobi, Kenya: International Council for Research in Agroforestry.

Arnstein, S. R. (1969). A ladder of citizen participation. Journal of the American Planning Association, 35(4), 216-224. https://doi.org/10.1080/01944366908977225

Astuti, T., \& Simarmata, M. M. T. (2020). Participation and community motivation to protect the Forest Park of Bukit Barisan. International Research Journal of Management, IT and Social Sciences, 7(5), 78-88. https://doi.org/https://doi.org/10.21744/irjmis.v7n5.973

Badan Pusat Statistik. (2019). Berita Resmi Statistik: Profil Kemiskinan di Indonesia September 2018. Jakarta, Indonesia: Badan Pusat Statistik.

Badan Pusat Statistik Kabupaten Pesawaran. (2019). Produk domestik regional bruto Kabupaten Pesawaran menurut pengeluaran 2014 - 2018. Kabupaten Pesawaran: Badan Pusat Statistik Kabupaten Pesawaran.

Barokah, U., Rahayu, W., \& Sundari, M. T. (2014). Analisis biaya dan pendapatan usahatani padi di Kabupaten Karanganyar. Agric Jurnal Ilmu Pertanian, 26(1), 12-19. https://doi.org/10.24246/agric.2014.v26.i1.p12-19

Berlan, A., \& Berges, A. (2013). Cocoa production in the Dominican Republic: Sustainability, challenges and opportunities. Report of findings commissioned by 
Green \& Black's. Menchester, Inggris.

Bowler, D. E., Buyung-ali, L. M., Healey, J. R., Jones, J. P. G., Knight, T. M., \& Pullin, A. S. (2012). Does community forest management provide global environmental benefits and improve local welfare? Frontiers in Ecology and The Environment, 10(1), 29-36. https://doi.org/10.1890/110040

BPS-Statistics of Lampung Province. (2019). Lampung Province in Figures 2019. Lampung, Indonesia: BPS-Statistics of Lampung Province.

BPS-Statistics of Pesawaran Regency. (2018). Pesawaran Regency in figures 2018. Pesawaran, Lampung, Indonesia: BPS Kabupaten Pesawaran.

BPS-Statistics of Pesawaran Regency. (2020). Pesawaran Regency in figures 2020. Pesawaran, Lampung, Indonesia: BPS-Statistics of Pesawaran Regency.

Braga, D. P. P., Domene, F., \& Gandara, F. B. (2018). Shade trees composition and diversity in cacao agroforestry systems of southern Para, Brazilian Amazon. Agroforestry Systems, 93(4), 1409-1421. https://doi.org/10.1007/s10457-0180250-6

Cerda, R. H., Deheuvels, O., Calvache, D., Niehaus, L., Saenz, Y., Kent, J., ... Somarriba, E. (2014). Contribution of cocoa agroforestry systems to family income and domestic consumption: looking toward intensification. Agroforestry Systems, 88(6), 957-981. https://doi.org/10.1007/s10457-014-9691-8

Chakraborty, M., Haider, M. Z., \& Rahaman, M. M. (2015). Socio-economic impact of cropland agroforestry: Evidence from Jessore District of Bangladesh. International Journal of Research in Agricultural and Forestry, 2(1), 11-20.

Chomitz, K. M. (2007). At loggerheads? Agricultural expansion, poverty reduction, and environment in the tropical forests; $A$ World Bank policy research report. Washington DC.

Cleaver, F. (1999). Paradoxes of participation: questioning participatory approaches to development. Journal of International Development, 11, 597-612.

Daeli, W., Tauhid, K., Maharani, C., Moeliono, M., \& Bong, I. W. (2017). Dari partisipasi ke inklusi: Pembelajaran dari desain dan pelaksanaan proyek pembangunan di Kapuas hulu, Kalimantan Barat. Info Brief CIFOR, (164), 1-8. https://doi.org/10.17528/cifor/006336

Deheuvels, O., Xavier, G., Grimaldo, R., Quiroga, S., Decker, M., Rolando, F., ... Somarriba, E. (2014). Biodiversity is affected by changes in management intensity of cocoa-based agroforests. Agroforestry Systems, 88(6), 1081-1099. https://doi.org/10.1007/s10457-014-9710-9

Desmiwati, D., Veriasa, T. O., Aminah, A., Safitri, A. D., Agus, K., Hendarto, ... Sari, D. R. (2021). Contribution of agroforestry systems to farmer income in state forest areas : A case study of Parungpanjang, Indonesia. Forest and Society, 5(1), 109119. http://dx.doi.org/10.24259/fs.v5i1.11223

Direktorat Jenderal Perkebunan (2017). Ringkasan tinjauan penetapan batas luas penggunaan lahan pada usaha perkebunan. Jakarta, Indonesia: Direktorat Jenderal Perkebunan, Kementerian Pertanian.

Duguma, B., Gockowski, J., \& Bakala, J. (2001). Smallholder cacao (Theobroma cacao Linn .) cultivation in agroforestry systems of West and Central Africa : challenges and opportunities. Agroforestry System, 51, 177-188.

Essouma, F. M., Isabelle, M., Mala, W. A., Levang, P., Ambang, Z., Boyogueno, A. D. B., ... Carriere, S. M. (2020). Cocoa-based agroforestry system dynamics and trends in the Akongo subregion of central Cameroon Franc. Agroforestry Systems, 1-12. 
https://doi.org/10.1007/s10457-020-00510-9

Handoko, H., \& Darmawan, A. (2015). Perubahan tutupan hutan di Taman Hutan Raya Wan Abdul Rachman (TAHURA WAR). Jurnal Sylva Lestari, 3(2), 43-52. Retrieved from http://dx.doi.org/10.23960/jsl2343-52

Hanif, M. A., Roy, R. M., Bari, M. S., Ray, P. C., Rahman, M. S., \& Hasan, M. F. (2018). Livelihood improvements through agroforestry: Evidence from Northern Bangladesh. Small-Scale Forestry, 17(4), 505-522. https://doi.org/10.1007/s11842-018-9400-y

He, S., Yang, L., \& Min, Q. (2020). Community participation in nature conservation : The Chinese experience and its implication to National Park Management. Sustainability, 12(4760), $17 . \quad$ Retrieved from www.mdpi.com/journal/sustainability

Humas Provinsi Lampung. (2017). UMP Lampung tahun 2018 sebesar Rp 2.074.673,27. Irshad, M., Khan, A., Inoue, M., Ashraf, M., \& Sher, H. (2011). Identifying factors affecting agroforestry system in Swat, Pakistan. African Journal of Agricultural Research, 6(11), 2586-2593. https://doi.org/10.5897/AJAR11.485

Jagoret, P., Kwesseu, J., Messie, C., Michael-Dounias, I., \& Malezieux, E. (2014). Farmers ' assessment of the use value of agrobiodiversity in complex cocoa agroforestry systems in central Cameroon. Agroforestry System, 88(6), 983-1000. https://doi.org/10.1007/s10457-014-9698-1

Jumiyati, S., Arsyad, M., Rajindra, Pulubuhu, D. A. T., \& Hadid, A. (2018). Cocoa based agroforestry: An economic perspective in resource scarcity conflict era. IOP Conference Series: Earth and Environmental Science, 6 p. https://doi.org/doi :10.1088/1755-1315/157/1/012009

Kalaba, K. F., Chirwa, P., Syampungani, S., \& Ajayi, C. O. (2010). Contribution of agroforestry to biodiversity and livelihoods improvement in rural communities of Southern African regions. In Tropical Rainforests and Agroforests under Global Change (pp. 461-462). https://doi.org/10.1007/978-3-642-00493-3

Kalonga, S. K., Kulindwa, K. A., \& Mshale, B. I. (2015). Equity in distribution of proceeds from forest products from Certified Community-Based Forest Management in Kilwa District, Tanzania. Small-Scale Forestry, 14(1), 73-89. https://doi.org/10.1007/s11842-014-9274-6

Kaplale, R. (2011). Analisis tingkat usahatani kakao ( Theobroma cacao L) Studi kasus di Desa Latu Kecamatan Amalatu. Jurnal Ilmiah Agribisnis dan Perikanan, 4(2), 60-68. https://doi.org/10.29239/j.agrikan.4.2.60-68

Lewis, L. K., \& Russ, T. L. (2012). Soliciting and using input during organizational change initiatives: What are practitioners doing. Management Communication Quarterly, 26(2), 267-294. https://doi.org/10.1177/0893318911431804

Mahmood, M. I., \& Zubair, M. (2020). Farmer's perception of and factors influencing agroforestry practices in the Indus River Basin, Pakistan. Small-Scale Forestry, 19(1):107-122. https://doi.org/10.1007/s11842-020-09434-9

Mak, B. K. L., Cheung, L. T. O., \& Hui, D. L. H. (2017). Community participation in the decision-making process for sustainable tourism development in Rural Areas of Hong Kong , China. Sustainability, 9(1695), 13. https://doi.org/10.3390/su9101695

Minarningsih \& Murniati. (2020). Complex agroforestry system in Wan Abdul Rachman Grand Forest Park : composition and characteristics of food-producing plants. IOP Conference Series: Earth and Environmental Science, $14 \mathrm{p}$. 
https://doi.org/10.1088/1755-1315/533/1/012018

Ministry of Agriculture. (2019a). Tree crop estate statistic of Indonesia 2018-2020: Cocoa. Jakarta, Indonesia: Directorate General of Estates, Ministry of Agriculture.

Ministry of Agriculture. (2019b). Tree crop estate statistics of Indonesia 2018-2020: Rubber. Jakarta, Indonesia: Directorate General of Estates, Ministry of Agriculture.

Ministry of Agriculture. (2019c). Tree crop estate statistics of Indonesia 2018-2020: Clove. Jakarta, Indonesia: Directorate General of Estates, Ministry of Agriculture.

Ministry of Agriculture. (2019d). Tree crop estate statistik of Indonesia 2018 - 2020: Nutmeg. Jakarta, Indonesia: Directorate General of Estates, Ministry of Agriculture.

Ministry of Environment and Forestry. (2020). The State of Indonesia's forests 2020. Jakarta, Indonesia: Ministry of Environment and Forestry, Republic of Indonesia. $189 \mathrm{p}$.

Montenegro, J. D., Varela, E., \& Gil, J. M. (2018). Livelihood strategies of cacao producers in Ecuador : Effects of national policies to support cacao farmers and specialty cacao landraces. Journal of Rural Studies, 63, 141-156. https://doi.org/10.1016/j.jrurstud.2018.08.004

Moorman, M. C., Peterson, N., Moore, S. E., \& Donoso, P. J. (2013). Stakeholder perspectives on prospects for co-management of an old-growth forest watershed near Valdivia, Chile. Society and Natural Resources, 26(9), 1022-1036. https://doi.org/10.1080/08941920.2012.739676

Mshale, B., Senga, M., \& Mwangi, E. (2017). Governing mangroves: Unique challenges for managing Tanzania's coastal forests. Bogor, Indonesia: CIFOR

Murniati, Yeni, I., Minarningsih, \& Sumarhani. (2019). Introducing sustainable agroforestry to encourage implementation of social forestry in Gedong Wani Forest Management Unit, Lampung , Indonesia. Proceeding of International Workshop and Seminar Innovation of Environmental-Friendly Agrcultural Technology Supporting Sustainable Food Self-Suffiency, 789-800. https://doi.org/10.5281/zenodo.3345863

Nath, T. K., Jashimuddin, M., \& Inoue, M. (2016). Community-Based Forest Management (CBFM) in Bangladesh: A historical bacground. In M. Palo \& J. Uusivuori, (Eds.), Community-Based Forest Management (CBFM) in Bangladesh. World Forest XXII, 17-28. https://doi.org/DOI 10.1007/978-3-319-42387-6

Ndalama, E., Thole, G. K., \& Missanjo, E. (2015). Agroforestry contribution to the improvement of rural community livelihoods in Balaka, Malawi. International Journal of Forestry and Horticulture, 1(1), 5-11. Retrieved from www.arcjournals.org

Ndayambaje, J. D., Heijman, W. J. M., \& Mohren, G. M. J. (2012). Household determinants of tree planting on farms in Rural Rwanda. Small-Scale Foretry, 11, 477-508. https://doi.org/10.1007/s11842-012-9196-0

Niehaus, L. A. (2011). Contribution of cacao (Theobroma cacao) agroforestry systems to the household economy of small-scale producers in Central America: The case of Bocas del Toro, Panama. Norwegian University of Life Science. Retrieved from http://hdl.handle.net/11250/189433

Notaro, M., Gary, C., \& Deheuvels, O. (2020). Plant diversity and density in cocoa-based agroforestry systems: how farmers ' income is affected in the Dominican 
Republic. Agroforestry Systems, 94(3), 1071-1084. https://doi.org/10.1007/s10457-019-00472-7

Nurlia, A., Martin, E., \& Winarno, B. (2015). Pengelolaan kolaboratif kawasan hutan di Tahura WAR. Prosiding Seminar Hasil Penelitian BP2LHK Palembang, (11 August 2015), 229-235. Retrieved from https://www.researchgate.net/publication/323258377

Oke, D. O., \& Odebiyi, K. A. (2007). Traditional cocoa-based agroforestry and forest species conservation in Ondo State, Nigeria. Agriculture, Ecosystem and Environment, 122, 305-311. https://doi.org/10.1016/j.agee.2007.01.022

Ostrom, E. (1990). Governing the commons: The evolution of institutions for collective action. Cambrige University Press. 280p.

Parhusip, S., Suharti, S., Sukandi, T., Amano, M., \& Matsumura, N. (2019). Economic analysis of local people's involvement in Community-Based Forest Management (CBFM) in Desa Ciomas, Indonesia. Japan Society of Forest Planning 25, 1-14. https://doi.org/10.20659/jfp.2019.002

Parrish, J., Reitsma, R., \& Greenberg, R. (1998). Cacao as crop and conservation tool. In First Sustainable Workshop on Sustainable Cocoa Growing (20p). Retrieved from http://www.nationalzoo.si.edu/smbc/Research/Cacao/cacao.asp

Pretty, J., \& Bharucha, Z. P. (2014). Sustainable intensification in agricultural systems. Annals of Botany., 114(8), 1571-1596. https://doi.org/10.1093/aob/mcu205

Pretty, J., Toulmin, C., \& Williams, S. (2011). Sustainable intensification in African agriculture. International Journal of Agricultural Sustainability, 9(1), 5-24. https://doi.org/10.3763/ijas.2010.0583

Rapsomanikis, G. (2015). The economic lives of smallholder farmers: An analysis based on household data from nine countries. FAO. https://doi.org/10.13140/RG.2.1.3223.9440, 48p.

Rice, R., \& Greenberg, R. (2000). Cacao cultivation and the conservation of biological diversity. AMBIO A Journal of The Human Environment, 29(3), 167-173. https://doi.org/10.1639/0044-7447(2000)029

Ruf, F., \& Schroth, G. (2004). Chocolate forests and monocultures: A historical review of cocoa growing and its conflicting role in tropical deforestation and forest conservation. In G. Schroth, G. A. B. da Fonseca, C. A. Harvey, C. Gascon, H. L. Vasconcelos, \& A.-M. N. Izac (Eds.), Agroforestry and biodiversity conservation in tropical landscapes (pp. 107-134). Washington, DC, US, Island press: Island Press.

Schroth, G., Harvey, C. A., \& Vincent, G. (2004). Complex agroforests:Their structure, diversity, and potential role in landscape conservation. In G. Schroth, G. A. B. da Fonseca, C. A. Harvey, C. Gascon, H. L. Vasconcelos, \& A.-M. N. Izac (Eds.), Agroforestry and Biodiversity Conservation in Tropical Landscapes (pp. 227260). Retrieved from https://www.researchgate.net/publication/ 40777441\%0AAgroforestry

Sikerbol, K. (2016). Participation or pseudo-participation? Change agent challenges in implementing organizational change. Retrieved from https://irc.queensu.ca/participation-or-pseudo-participation-change-agentchallenges-in-implementing-organizational-change/

Sonwa, D. J., Weise, S. F., Schroth, G., Janssens, M. J. J., \& Shapiro, H.-Y. (2014). Plant diversity management in cocoa agroforestry systems in West and Central Africa - effects of markets and household needs. Agroforestry Systems, 88(6), 1021- 
1034. https://doi.org/10.1007/s10457-014-9714-5

Sugiana, A. M. (2012). Collective action and ecological sensibility for sustainable mangrove governance in Indonesia: Challenges and opportunities. Journal of Political Ecology, 19(1), 184-201. https://doi.org/10.2458/v19i1.21726

Suharti, S. (2001). Increased community participation in forest management through the development of social forestry programmes in Indonesia. In P. J. M. Hillegers \& H. H. longh (Eds.), The Balance between Biodiversity Conservation andSustainable Use of Tropical Rain Forests (pp. 233-244). The Tropenbos Foundation, Wageningen, the Netherlands.

Tetteh, D. A., Asase, A., Ofori-frimpong, K., \& Attuquayefio, D. (2018). Effect of cocoa farming intensification on biodiversity and ecosystem properties in Southern Ghana. Journal of Ecology and The Natural Environment, 10(September), 172181. https://doi.org/10.5897/JENE2017.0673

Thwala, W. D. (2010). Community participation is a necessity for project success : A case study of rural water supply project in Jeppes Reefs, South Africa. African Journal of Agricultural Research, 5(10), 970-979. https://doi.org/10.5897/AJAR09.700

Uphoff, N. (1985). Participatory evaluation of participatory development: A scheme for measuring and monitoring local capacity. Ithaca, New York: Center for International Studies, Cornell University.

Uphoff, N. (1992). Local institutions and participation for sustainable development. Gatekeeper Series $\quad$ No. Retrieved from http://www.jstor.com/stable/resrep01670

UPTD Tahura WAR. (2017). Blok pengelolaan Taman Hutan Raya Wan Abdul Rachman, Provinsi Lampung. Bandar Lampung, Lampung: UPTD Tahura Wan Abdul Rachman.

Vaast, P., \& Somarriba, E. (2014). Trade-offs between crop intensification and ecosystem services: The role of agroforestry in cocoa cultivation. Agroforest Systems, 88(6), 947-956. https://doi.org/10.1007/s10457-014-9762-x

Vebrova, H., Lojka, B., Husband, T. P., Elena, M., Zans, C., Damme, P. Van, ... Kalousova, M. (2013). Tree diversity in cacao agroforests in San Alejandro, Peruvian Amazon. Agroforest Systems, 88(6), 1101-1115. https://doi.org/10.1007/s10457-0139654-5

Winata, A., \& Yuliana, E. (2012). Tingkat partisipasi petani hutan dalam Program Pengelolaan Hutan Bersama Masyarakat ( PHBM ) Perhutani. MIMBAR, XXVII/(1), 65-76.

World Bank Group. (2018). Piecing together the poverty puzzle; Poverty and sahred prosperity 2018. World Bank Publications.

Wulandari, C., Bintoro, A., Rusita, Santoso, T., Duryat, Kaskoyo, H., ... Budiono, P. (2018). Community forestry adoption based on multipurpose tree species diversity towards to sustainable forest management in ICEF of University of Lampung , Indonesia. Biodiversitas, 19(3), 1102-1109. https://doi.org/10.13057/biodiv/d190344

Wulandari, C., Budiono, P., Yuwono, S. B., \& Herwani, S. (2014). Adoption of agroforestry patterns and crop systems around Register 19 Forest Park, Lampung Province, Indonesia. Jurnal Manajemen Hutan Tropika, XX(2), 86-93. https://doi.org/10.7226/jtfm.20.2.86

Yeny, I., Murniati, \& Octavia, D. (2017). Hubungan karakteristik internal petani dengan keberhasilan pertumbuhan cempaka (Michelia champaca L.) di demplot hutan 
rakyat. Jurnal Penelitian Hutan Tanaman, 14(1), 35-49. https://doi.org/https://doi.org/10.20886/jpht.2017.14.1.35-49

Yeny, I., Murniati, \& Suharti, S. (2020). Partisipasi masyarakat dalam wilayah pengembangan agroforestry di Kesatuan Pemangkuan Hutan (KPH) Gedong Wani. Jurnal Penelitian Sosial Dan Ekonomi Kehutanan, 17(1), 49-66. http://dx.doi.org/10.20886/jtsek.2020.17.1.49-66 